\title{
Research and Development on Biomass Energy in China
}

\author{
Yuan Zhenhong \\ Professor, general Secretary \\ China Biomass Development Center \\ June 2001, Beijing, China
}

\begin{abstract}
Like developed country, China is facing two serious constraints, energy shortage and environment pollution, which will hinder the development of national economy and improvement of living standards. It is estimated that the total biomass resources is up to $5.2 \times 10^{8} \mathrm{TOE}$ in which crop residue resource is up to $2.7 \times 10^{8}$ TOE, firewood over $5.2 \times 10^{7} \mathrm{TOE}$ and animal dung about $1.0 \times 10^{8} \mathrm{TOE}$. Meanwhile, Biomass is a clean energy resource and can explored as a convenient energy in the next century. Since 1980, several institutes have developed various biomass energy conversion technologies and applied successfully in rural areas. Up to 1999 , there is about 1.58 million TOE of energy came from biomass energy through energy saving technology and biomass energy conversion technology. In the future, China will develop biomass energy in a large scale. By 2010, energy provided by these technologies will have been up to 14.1 million TOES. Through these technologies, biomass will give us more benefits on energy, environment and economy. Of course, we should resolve some problems, such as technical, economical, political and financial problems.
\end{abstract}

Keyword: biomass, gasification, liquefaction, brequitting, biogas, alcohol, energy, environment, greenhouse gas, $\mathrm{CO}_{2}$, crop residues, sawdust, firewood, animal dung

\section{Introduction}

\subsection{Related position of agriculture and rural sector in the national economy}

\subsubsection{Population}

China has a hug population, which covers one fourth of the globe population. In the past 16 years, the population had been growing yearly at an average natural growing rate of $1.44 \%$. By 1999, the population had been about 1.259 billions, of which about $69.1 \%$ was rural population, and the rate of population nature increasing kept at $8.77 \%$.

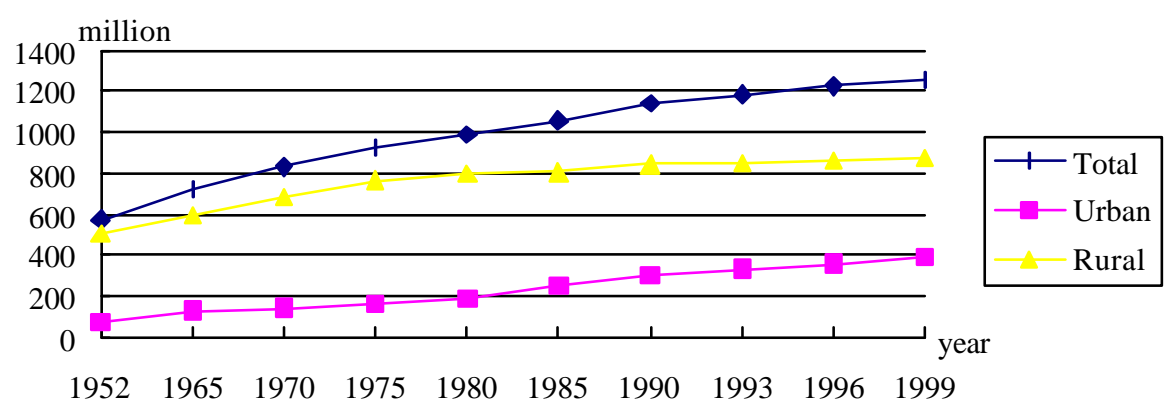

Fig.1 Population and its distribution in China (1952-1999)

China also is an agricultural country that about $69.1 \%$ of its population was rural population and $30.9 \%$ was urban population in the same year (Fig.1).

On the other hand, the proportion between the rural population and the urban population has been changing a great deal in recent years. From Fig.2, it is shown clearly that the proportion of population had a little change from 1952 to 1980 , only $6 \%$ for 28 years, but it 
has been a great change from 1980 to 1999 , up to $10 \%$ for 20 years. It is one of reasons that there is a quick population migration between rural areas and cities. The migration may be resulted from a great achievement on the national economy having been made in this period.

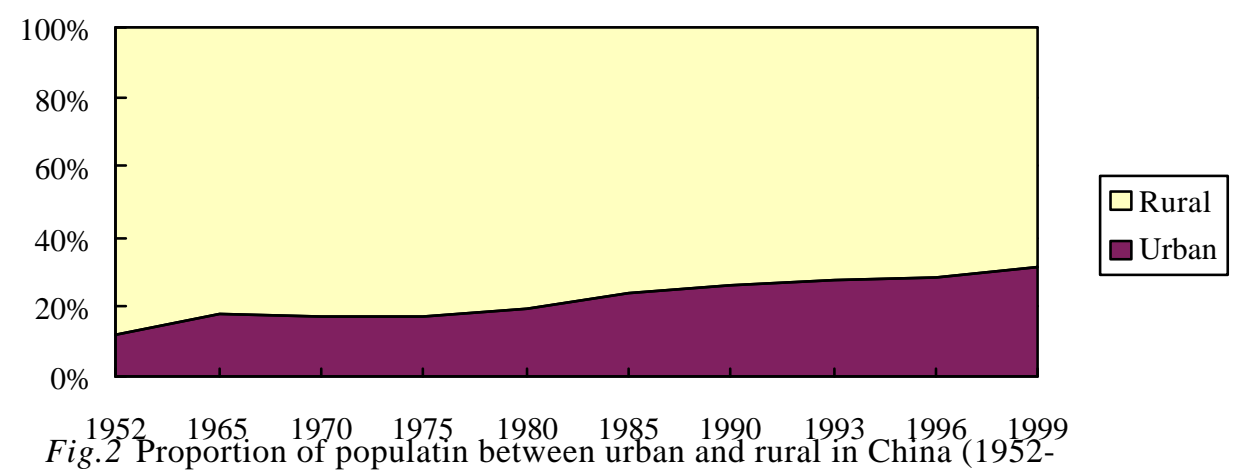

1999)

By now, Chinese population is still growing at a high rate, even though a population program in the whole country has controlled it for the last two decades. For instance, the natural growth rate of population was up to $1.145 \%$ in 1993 . By 2050 , Chinese population will have been up to 1.55 billions (Table 1) and the proportion of rural population to total population will have been changed greatly from $80 \%$ in 1985 down to $25-35 \%$ (Table 2).

Table 1. Chinese population in the future (2000-2050)*

\begin{tabular}{|c|c|}
\hline Years & Population (millions) \\
\hline 2000 & 1,248 \\
2015 & 1,396 \\
2030 & 1,512 \\
2050 & 1,550 \\
\hline
\end{tabular}

*From a report by the World Bank.

Table 2. Proportion of rural population to total population (\%) (2000-2050)

\begin{tabular}{|c|c|c|c|}
\hline 2000 & 2020 & 2030 & 2050 \\
\hline 70 & 63 & 50 & $25-35$ \\
\hline
\end{tabular}

\subsubsection{Status of the national economy}

Since opening its door to the outside world in 1980's, China has been deepening process of economic and political restructure and marching towards to an establishment of a socialist market economy with Chinese Characteristics. By 1998, China had made a great achievement in its social and economic stability and sustained economic development. In this year, the GNP was up to 7800 billion RMB, about 3 times as much as that in 1985 . The average annual increasing rate of GNP was over 6.6\% from 1978 to 1993, and the rate was about $10.5 \%$ from 1991 to 1998 (Fig.3). 


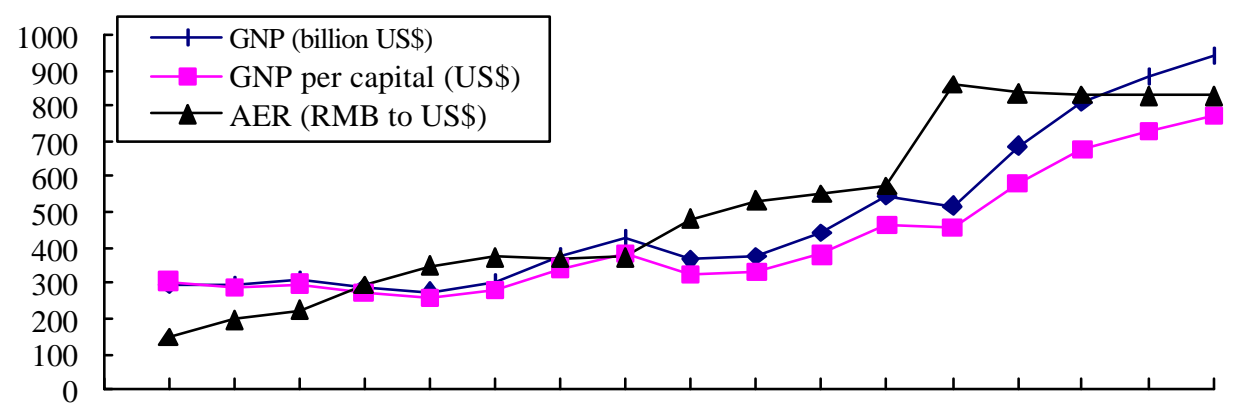

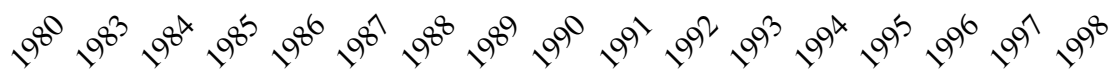

* Values in the figure are based on current prices and average exchange rates of RMB Yuans for 100 US\$ in these fiscal years respectively.

Fig.3 A curve of economy development in China from 1980 to 1998

In Fig. 3, there are three peaks of economy growing, but there is no decreasing clearly. One exists between 1988 and 1989, annual increasing rates of GNP are 25\% and 14\% respectively in these two years, second one is between 1992 and 1993, and annual increasing rates of GNP are $17 \%$ and $23 \%$ respectively in these two years, the third one is at 1997-1998. In China, the rate is mainly contributed by three economic sectors, primary industry, second industry and tertiary industry. In 1988, for example, the rates for the three sectors are $25.7 \%, 44.1 \%$ and $30.2 \%$ of the total GNP respectively. In the second peak, they are $21.8 \%, 43.9 \%$ and $34.3 \%$ respectively in 1992 , and $19.9 \%, 47.4 \%$ and $32.7 \%$ respectively in 1993 . In the third peak, they are $19.9 \%, 50 \%$ and $30.1 \%$ respectively in 1997, and $18.6 \%, 49.3 \%$ and $32.1 \%$ respectively in 1998.

A research result on the increasing of Per Capital GNP in the first half of the next century is shown in the table 3 .

Table 3 A Prediction for Per Capital GNP (US\$) 2000-2050

\begin{tabular}{|c|c|c|c|c|}
\hline Proposalslyears & 2000 & 2020 & 2030 & 2050 \\
\hline 1 & 1,000 & 2,500 & 3,350 & 6,000 \\
\hline 2 & 1,000 & 1,900 & 2,450 & 4,000 \\
\hline
\end{tabular}

\subsubsection{Position of agriculture and rural economy in the national economy}

China is an agricultural country, that is, the rural economy is one of the most important sectors in the national economy. As shown in the table 4, the GNP of primary industry, agriculture, occupies about $17.7 \%$ of the total GNP in the country.

Table 4. Gross National Products and National Income in 1999

\begin{tabular}{|c|c|c|c|c|c|}
\hline Items & Total & $\begin{array}{c}\text { Primary } \\
\text { Industry }\end{array}$ & $\begin{array}{c}\text { Second } \\
\text { Industry }\end{array}$ & $\begin{array}{c}\text { Tertiary } \\
\text { Industry }\end{array}$ & $\begin{array}{c}\text { Per capital } \\
\text { (US\$) }\end{array}$ \\
\hline GNP (billion US\$) & 1011.3 & 178.5 & 499 & 333.8 & 807 \\
$\%$ & 100 & 17.65 & 449.34 & 33.01 & \\
\hline
\end{tabular}

In the table 4 , the primary industry means agriculture, including farming, forestry, animal 
husbandry and fishery; the second industry is composed of manufacture, mining, processing, construction etc.; and the tertiary industry is related to transportation, communication, commerce and other public service facilities. In fact, the so-called rural industry involved in the second industry and tertiary industry has become an important sector in the rural economy since 1980's (Fig. 4). Since 1994, there have not been any official statistics data on rural industry in the country.

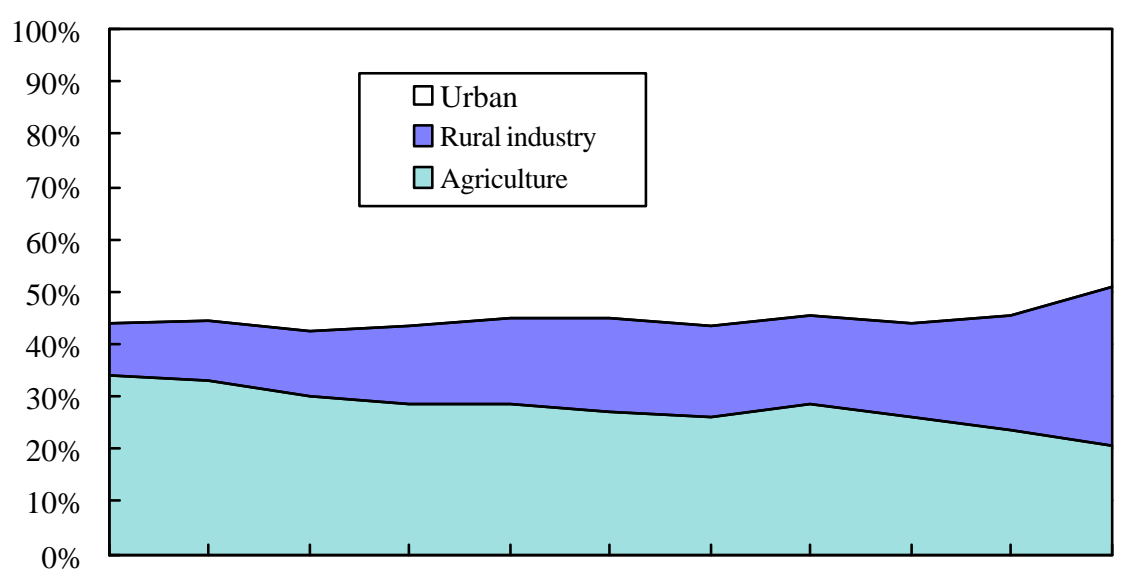

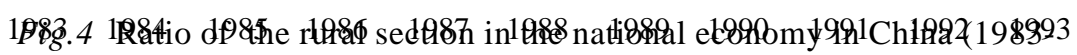
1993)
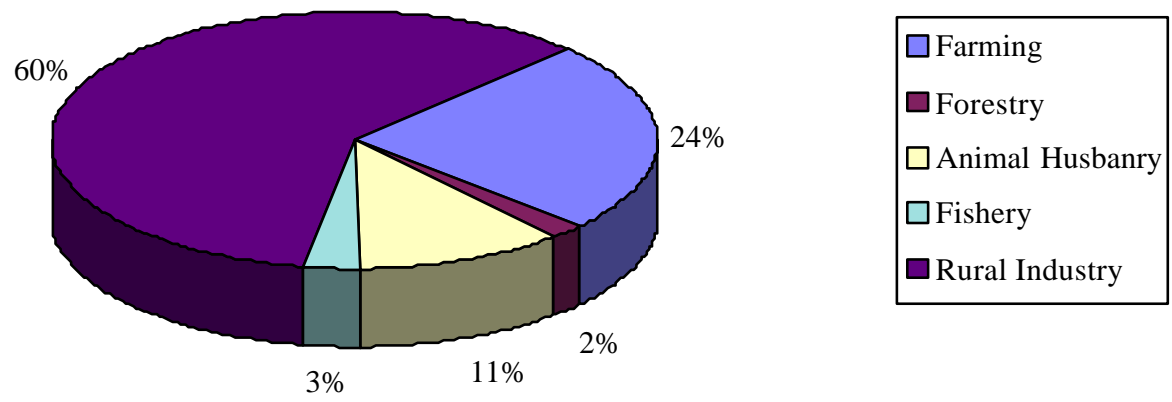

$3 \%$

Fig. 5 Composition of the rural economy in 1993(GNP of 277.9 billion US\$ in total)

From Fig. 4, the rural industry had been growing at a high speed in the decade. In 1983, the rural industry occupied only $9 \%$ of the national economy, however, by 1993, its sector had gone up to $30 \%$ of the national economy. Concerning the rural industry, the rural economy had covered about $51 \%$ of the total national economy in 1993, about 277.8 billion US\$ of GNP.

In the rural economy, there was about $60 \%$ from the rural industry, but farming, forestry, animal husbandry and fishery was $24 \%, 2 \%, 11 \%$ and $3 \%$ respectively in 1993(Fig.5).

\subsection{Energy supply situation in the country}

It is well known that the growth of national economy and the progress of society must rely on the development of energy industry. In nowadays, commerce energy is mainly composed of fossil fuels, however, fossil fuels, such as coal, petroleum and natural gas, is limited greatly by their resources and will be used up in the future. 


\subsubsection{Energy production}

In recent years, China has paid more attention on developing its energy industry to meet more and more energy demand for the growth of national economy and the improvement of living level. In china, the coal mining industry is the most important energy industry and coal energy is the biggest part of energy sources, while the oil and natural gas energy industry and the electricity industry have been greatly developed only in the recent 50 years.

In 1953, about 70 million of coal, 0.62 million tones of oil, 11 million $\mathrm{M}^{3}$ of natural gas and 1.5 billion kwh of hydro-electricity was produced and occupied respectively about $97.88 \%$, $1.73 \%, 0.03 \%$ and $0.36 \%$ of total primary energy production, 35.76 million TOE. From 1985 to 1997 , the total primary energy production had been increased by $5.7 \%$ yearly. In 1985, the primary energy production was 599 million TOEs, in 1993, the primary energy production was 779 million TOEs, in 1997, the primary energy production was up to 927 million TOEs, but in 1999, the primary energy production was decreased deeply, about 770 million TOE, in which there was 1,072 million tones of coal, 161 million tones of oil, 26.5 billion $\mathrm{M}^{3}$ of natural gas and 203 billion kwh of hydro-electricity (Fig.6 and Table 5).
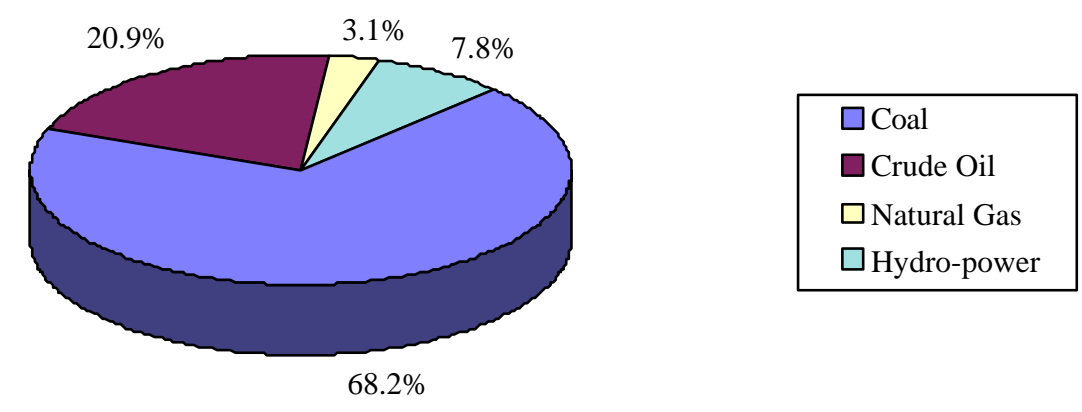

Fig. 6 Production and composition of primary energy

(770 million TOE in total, 1999)

Table 5. The Primary Energy Production in China (1952-1999)

\begin{tabular}{|c|c|c|c|c|c|}
\hline & \multirow{2}{*}{$\begin{array}{c}\text { Total } \\
\text { Years }\end{array}$} & \multicolumn{5}{|c|}{ Proportion ( ) } \\
\cline { 3 - 6 } & MTCE & Coal & Oil & Nature Gas & Hydro-Power \\
\hline 1952 & 48.71 & 96.7 & 1.3 & $\ldots$ & 2.0 \\
1962 & 171.85 & 91.4 & 4.8 & 0.9 & 2.9 \\
1970 & 309.90 & 81.6 & 14.1 & 1.2 & 3.1 \\
1975 & 487.54 & 70.6 & 22.6 & 2.4 & 4.4 \\
1980 & 637.35 & 69.4 & 23.8 & 3.0 & 3.8 \\
1985 & 855.46 & 72.8 & 20.9 & 2.0 & 4.3 \\
1990 & 1039.22 & 74.2 & 19.0 & 2.0 & 4.8 \\
1993 & 1110.59 & 74.0 & 18.7 & 2.0 & 5.3 \\
1996 & 1326.16 & 75.2 & 17.0 & 2.0 & 5.8 \\
1997 & 1324.10 & 74.1 & 17.3 & 2.1 & 6.5 \\
1998 & 1240.00 & 72.0 & 18.5 & 2.4 & 7.1 \\
1999 & 1100.00 & 68.2 & 20.9 & 3.1 & 7.8 \\
\hline
\end{tabular}

Note: MTCE means million tones of energy equal to standard coal

\subsubsection{Primary energy consumption}

As a developing country, China has been consuming more and more the primary energy, which is prompted by the development of its national economy in recent 30 years. In 1970, 
the total consumption of primary energy was only 205 million TOE in this country, of which about $81 \%$ came from coal energy. After 28 years later, in the year of 1998, the amount was up to 925.5 million TOE, about 5 times of that in 1970. From Fig.7 and table 6, it can be seen that consumption increasing rates of oil, natural gas and electricity is steeper than that of coal. It means that more and more clean energy, such as oil, nature gas and electricity, have been used in modern industries and daily life.

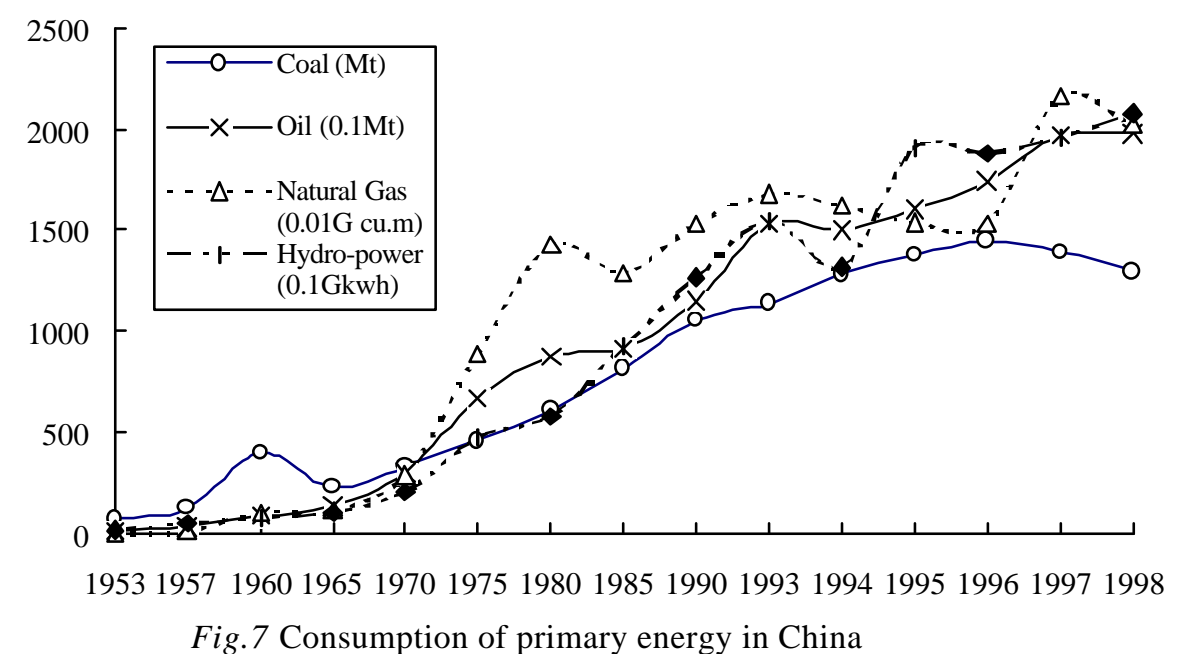

Table 6. The Primary Energy Consumption in China (1952-1999)

\begin{tabular}{|c|c|c|c|c|c|}
\hline \multirow{2}{*}{ Years } & \multirow{2}{*}{$\begin{array}{c}\text { Total } \\
\text { MTCE }\end{array}$} & \multicolumn{4}{|c|}{ Proportion (\%) } \\
\cline { 3 - 6 } & & Coal & Oil & Nature Gas & $\begin{array}{c}\text { Hydro- } \\
\text { power }\end{array}$ \\
\hline 1957 & 67.5 & 92.3 & 4.6 & 0.1 & 3.0 \\
1962 & 115.8 & 89.2 & 6.6 & 0.9 & 3.2 \\
1970 & 205.0 & 80.9 & 14.7 & 0.9 & 3.5 \\
1975 & 318.0 & 71.9 & 21.1 & 2.5 & 4.6 \\
1980 & 644.5 & 72.2 & 20.7 & 3.1 & 4.0 \\
1985 & 536.8 & 75.8 & 17.1 & 2.2 & 4.9 \\
1990 & 690.9 & 76.2 & 16.6 & 2.1 & 5.1 \\
1993 & 812.0 & 74.7 & 18.2 & 1.9 & 5.2 \\
1996 & 972.6 & 74.7 & 18.0 & 1.8 & 5.5 \\
1997 & 967.2 & 71.5 & 20.4 & 1.7 & 6.2 \\
1998 & 925.5 & 69.6 & 21.5 & 2.2 & 6.7 \\
1999 & 854.0 & 67.1 & 23.4 & 2.8 & 6.7 \\
\hline
\end{tabular}

Because these clean energy sources are playing more and more important roles in the national economic actions, the proportion of coal in the total national energy consumption is reduced gently in recent years. By 1999, the proportion of coal energy consumption had decreased to $67.1 \%$, but that of other primary energy sources, such as oil, natural gas and hydro-electricity had increased to $23.4 \%, 2.8 \%$ and $6.7 \%$ respectively (Fig.8). 


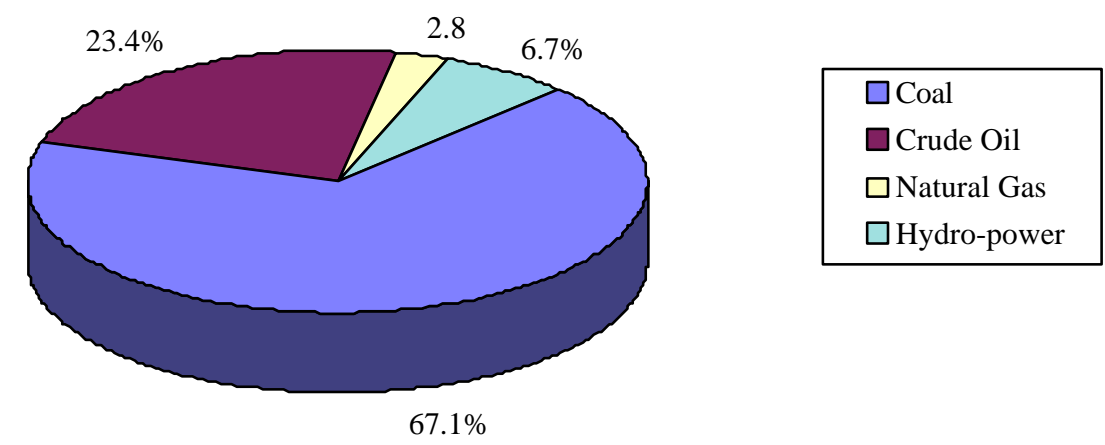

Fig. 8 Consumption and composition of primary energy in China (854 million TOE in total, 1999)

In order to produce the clean energy, a great amount of coal have been converted to second energy products, such as electricity, charcoal and coal oil. In 1993, about 335 million tones of coal, equal to 239 million TOEs, were used for power generation. The amount is about $29.4 \%$ of the total coal consumption of 1,140 million tones or equal to 570 million TOEs in this year.

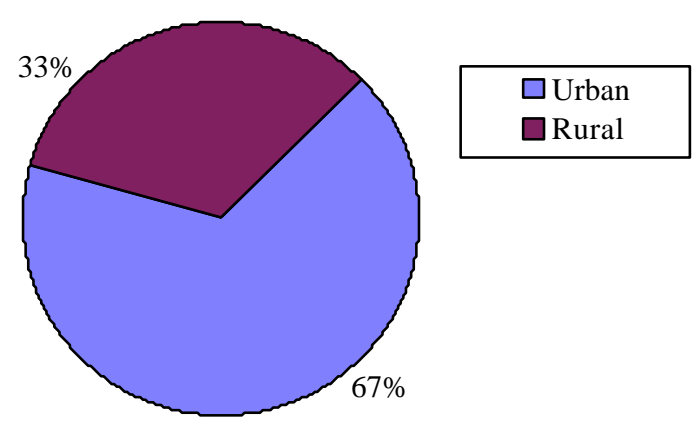

Fig. 9 Sector of rural commerce energy in 1999

But, in China rural area, the biomass energy is a main energy resource that is not included in all official statistics data. In fact, the total rural energy consumption was up to 462 million TOE in 1999, in which about 282 million TOE came from he commerce energy, occupied $33 \%$ of the total commerce energy consumption in the country, and other 180 million TOE came from biomass energy (Fig.9).

\subsubsection{Energy balance}

In fact, there is a big shortage in the energy providing market, even though China has done its bet to develop its energy industry in the recent years, that is, the energy production can not be enough to meet the energy demand due to a poor base facility and an investment shortage for developing energy industry in China.

In 1993, there was a shortage of 3 million TOE between energy production and energy consumption, that is, China has become an energy imported country which the amount of energy imported will be more than that of energy exported (Table 7).

Table 7 Primary Energy Balance in MTCE in China 


\begin{tabular}{|c|c|c|c|c|c|}
\hline Items & 1985 & 1990 & 1995 & 1997 & 1998 \\
\hline Total Providing Energy & $\mathbf{7 7 6 0 3}$ & $\mathbf{9 6 1 3 8}$ & $\mathbf{1 2 9 5 3 5}$ & $\mathbf{1 3 3 7 2 4}$ & $\mathbf{1 2 8 3 6 8}$ \\
Primary Energy Production & 85546 & 103922 & 129034 & 132410 & 124250 \\
Energy Saving & & & 2312 & 467 & 1920 \\
Input & 340 & 1310 & 5456 & 9964 & 8474 \\
Output (-) & 5774 & 5875 & 6776 & 7663 & 7153 \\
Deferent Yearly & -2509 & -3219 & -491 & -1453 & 878 \\
Primary energy Consumption & $\mathbf{7 6 6 8 2}$ & $\mathbf{9 8 7 0 3}$ & $\mathbf{1 3 1 1 7 6}$ & $\mathbf{1 3 8 1 7 3}$ & $\mathbf{1 3 2 2 1 4}$ \\
\hline
\end{tabular}

To consider the energy demand in rural areas, the shortage may be $10 \%$ in the whole country. Some factories have to stop their operation due to the energy shortage. Actually, in rural areas, the shortage must be over $30 \%$, thus cutting down forest has become a way to make compensation for the shortage.

\subsubsection{Prediction of Energy in the future}

It is well known that the energy consumption in a country is greatly related to the size of population and the scale of economic action in the country. According to some research works on population and economy in the future, the energy demand will be increased steeply in the next century. In a long-term prediction of energy demand in future, it is reported that the energy demand will be increased at a high speed as the growth of population and the development of economy in the country even though more and more new technologies will be used to save energy consumption.

From Table 7, the energy demand will be up to 3,780 million TOE by 2050, about 4.4 times as much as that of in 1999.

Table8 A prediction of total energy demand for $2000-2050$

\begin{tabular}{|c|c|c|c|}
\hline Items \Years & 2000 & 2020 & 2050 \\
\hline Population (million) & 1,256 & 1,380 & 1,550 \\
Per Capital GNP (US\$ in 1980) & 1,000 & 2,500 & 6,000 \\
GNP (billion US\$ in 1980) & 1,250 & 3,450 & 9,000 \\
Energy Demand (Mtoe) & $1,000-1,130$ & 2,100 & 3,780 \\
Per Capital Energy Consumption (Toe) & $0.80-0.90$ & 1.52 & 2.44 \\
Energy / GNP (kgoe/US\$) & 0.81 & 0.64 & 0.46 \\
Energy Saving in Average (\%/ year) & 3.3 & 1.0 & 1.0 \\
Elasticity of Energy Consumption & 0.61 & 0.72 & 0.61 \\
\hline
\end{tabular}

By survey data from related government divisions, it has been estimated that the total oil reserve may be up to 60 billion tones, the recoverable oil reserve will be 15 billion tones and the explored reserve is 3.3 billion tones in China in 1992; the total natural gas reserve may $30 \times 10^{12} \mathrm{M}^{3}$, the recoverable reserve can be $6.4 \times 10^{12} \mathrm{M}^{3}$ and the explored reserve is $1.4 \times 10^{12} \mathrm{M}^{3}$ in 1992; The total coal reserve may be 450 billion tones and the explored reserve is 985 billion tones. Based on these data and planning rates of economic growing, some research work has been made and several energy experts have obtained a similar 
result. In a report, it is pointed that the oil resource will have been exhausted by 2040, natural gas by 2060 and coal by 2300 .

\subsection{Utilization of agricultural/ forestry residues and other biomass as renewable energy source}

For a long history, China has been using biomass as energy. Especially in its rural areas, biomass can be utilized by a way of directly burning in a traditional stove, the heat efficiency only $10 \%$. Before 1979 , the biomass energy had covered about $70 \%$ of the rural energy consumption. Up to now, the biomass energy are still playing an important role on the rural energy, even though commerce energy sources, such as coal, oil and electricity, have been popularized in rural areas in the country (Fig.10).

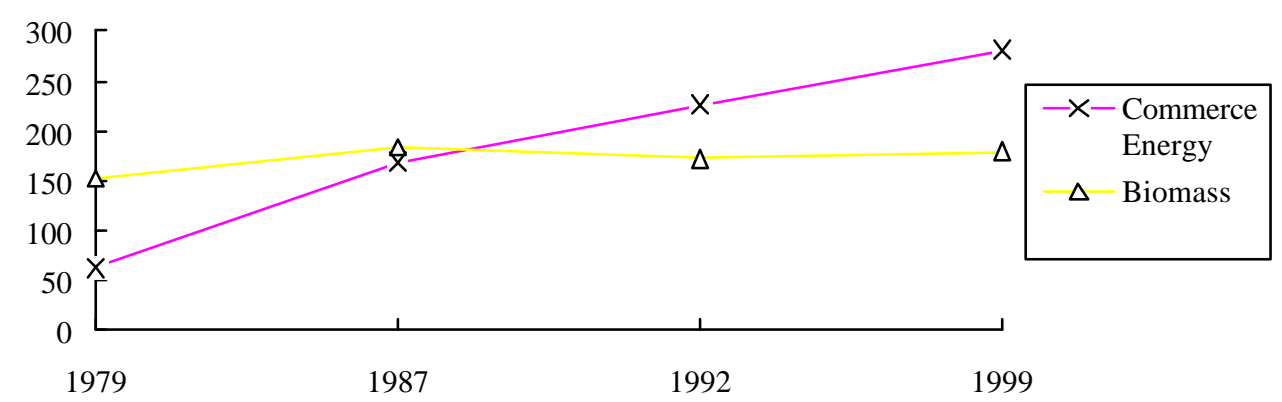

Fig.10 Changes of commerce energy and biomass energy in rural areas

In 1993, the total energy consumption in rural areas was $4.10 \times 10^{8} \mathrm{TOE}$, of which 2.46 $\times 10^{8}$ TOE was for the household energy consumption and $1.64 \times 10^{8}$ TOE for the rural industry energy consumption, respectively occupied $60 \%$ and $40 \%$ of the total amount.

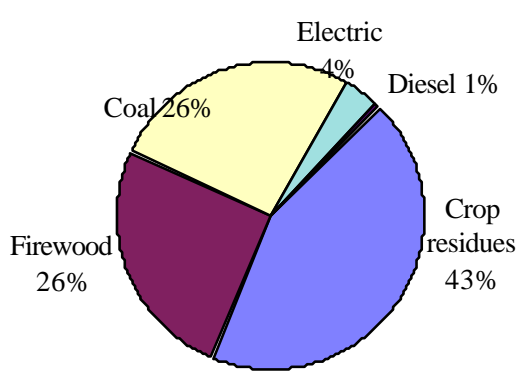

Fig.11 Consitution of household energy consumption in 1993 (246 MTOE)

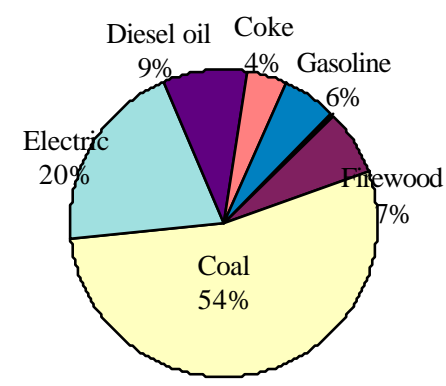

Fig.12 Consitution of rural industry energy consumption in 1993 (164 MTOE)

Furthermore, about $69 \%$ of the household energy consumption came from biomass, up to $1.70 \times 10^{8}$ TOE, of which $1.06 \times 10^{8}$ came from crop residues and $6.4 \times 10^{7}$ TOE from firewood (fig.11). In fig.12, it is shown that the rural industry energy consumption actually relies on coal and electricity, covering $54 \%$ and $20 \%$ respectively, only $7 \%$ came from biomass-firewood, about 22 million tones being equal to $1.1 \times 10^{7}$ TOE, which occupied $14.7 \%$ of the total amount of firewood consumed in the country. 


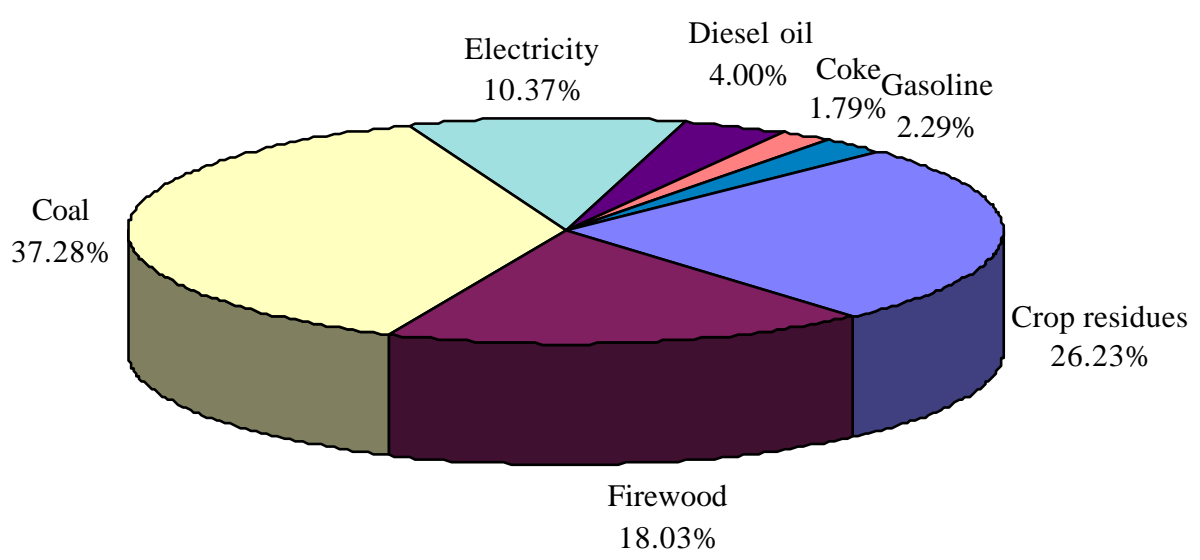

Fig.13 Consitution of the total rural energy consumption in 1993

(410 MTOE)

As shown in fig.13, the biomass energy consumed for household uses and industry occupied about 44\% of the total energy consumption in rural areas in 1993. Recently, in the rural energy consumption, the proportion of commercial energy including coal, electricity, oil and natural gas etc. has been going up in a large scope, although their prices are always much higher than that of biomass fuels. . In 1999, the total rural energy consumption was up to 464 million of TOEs, of which, about $30 \%$ came from biomass, mainly crop residues and firewood. Thus, it has become urgent to develop some advance processes for conversion of biomass to clean and convenient fuels in the country.

In the part 1.2 of this paper, the biomass energy is not included in the national energy consumption, that is, the statistical data is only for the commerce energy. If the biomass energy consumed in rural areas can be counted into the statistical data, the total energy consumption in the country could be about 1034 million TOEs in 1999. Thus the total consumption and composition of energy in China can be shown in the Fig. 14.

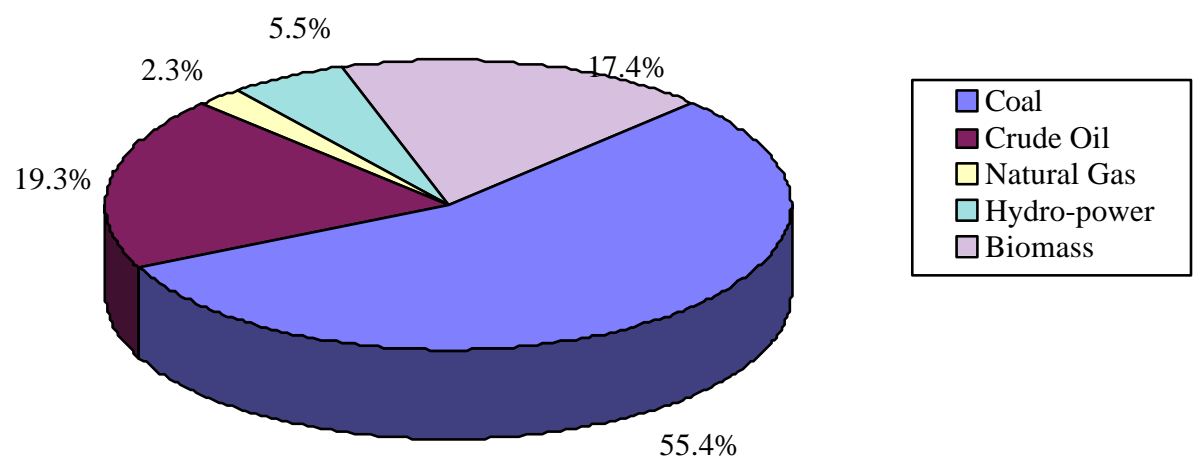

Fig. 14 total energy consumption and its composition

(1034 million TOE in total, 1999)

\subsection{Environment impacts of energy production and use}

It is well known that the production and consumption of energy is one of the most important human actions and is a prerequisite for the progress of human society. Meanwhile, the production and consumption of energy must cause a harmful pollution on the human living environment. In recent years, environment pollution has become a hot topic in the world due 
to its seriously limited effects on most of human actions, especially on the development of economy and the progress of society. In the modern human society, coal and oil are two important energy resources and their production and utilization in a large scale can bring a serious pollution on the globe environment, especially a great contribution to the GHG. As a developing country, China uses coal as its main energy source, over $67 \%$ of its total energy consumption in 1999, from which serious environment pollution has been caused in the whole country in recent years.

\subsubsection{Environment impacts of energy production}

Any kind of energy source, including coal, oil, natural gas, even though, and new and renewable energy, like hydro-electricity, nuclear energy, biomass, wind energy, terrestrial heat and solar energy, can cause more or less environmental effect when it is explored as an energy source.

In case of coal, its exploration in a large scale can cause a series of critical effects on environment:

- Causing earth's surface drooping down or earthquake by mining coal underground;

- Destroying earth's surface structures and bioecological systems by mining coal on the ground;

- Polluting underground water system;

- And producing many kinds of wastes, such as $\mathrm{CO}, \mathrm{SO}_{\mathrm{x}}, \mathrm{CO}_{2}, \mathrm{CH}_{4}$, gangue, coal powder and others, to pollute atmosphere layer and water system.

In case of oil and natural gas, their exploration can also cause a serious pollution on environment like the case of coal:

- Polluting waster system including underground water system and on the ground water system by waste oil;

- Destroying farmland and agri-ecological distribution by trilling mud and oil-bearing water;

- Making air pollution by water, gas and solid wastes from refining processes;

- Harming fishery production and maritime ecological systems by oil escaping from oil tankers or offshore oil fields.

Finally, some environment effects can be caused from explorations of other energy sources, for example:

- To build a hydro-electricity plant, a big water reservoir is needed certainly so that a large area of farmland, and/or forest will be inundated, natural ecological systems of agricultural and/or forest will be destroyed;

- To get enough wood energy, an over-cutting down of forest may be conducted;

- To explore geothermal energy in a long time, an earth's surface drooping down or earthquake may be caused from a change of geological structure;

- To operate a nuclear generation plant, radiation pollution may be caused from a nuclear escaping occasionally.

By 1999, the area of earth's surface drooping down caused by mining industry had been up to 2 million hectares, the area of farmland polluted by industrial wastes had been 10 million hectares, and the area of losing soil and water had been 150 million hectares. According a statistics, the area of farmland is reduced by 0.3 million hectares yearly. 


\subsubsection{Environmental impact of energy consumption}

In fact, a process of energy consumption is a process of pollution formation, that is, when a kind of fuel is utilized as an energy source, it is always in company with varied pollution from waste gas or other pollutants.

Coal and oil are two kinds of main energy sources in the world, which can cause very serious pollution on environments. Coal is mainly used to produce one or more kinds of second energy products, such as heat energy, gas fuel, liquid fuel and/or electricity, or burnt directly as a primary energy. Oil is mainly used to produce liquid fuels by a refining process, such as gasoline and diesel oil, or to generate electricity. From utilization of the two energy sources, air pollution by waste gases, such as $\mathrm{CO}, \mathrm{SO}_{\mathrm{x}}, \mathrm{CO}_{2}$ and $\mathrm{NO}_{\mathrm{x}}$, is one of the most serious effects on environments. In 1989, about 13.6 million tones of soot and 14.8 million tones of $\mathrm{SO}_{2}$ was produced by burning coal, which may contribute respectively $62 \%$ and $93 \%$ of their total emissions in the whole country. The table 9 shows levels of air pollution from industrial waste gases from 1990 to 1999. 
Table 9 Waste gases from industry production

\begin{tabular}{|c|c|c|c|c|c|}
\hline Years & $\begin{array}{c}\text { Total waste } \\
\text { gas }\left(10^{12}\right. \\
\left.\mathrm{M}^{3}\right)\end{array}$ & $\begin{array}{c}\text { Flue gas from } \\
\text { fuel } \\
\left(10^{12} \mathrm{M}^{3}\right)\end{array}$ & $\begin{array}{c}\mathrm{SO}_{2} \\
(\mathrm{Mt})\end{array}$ & $\begin{array}{c}\text { Soot } \\
(\mathrm{Mt})\end{array}$ & $\begin{array}{c}\text { Industrial Dust } \\
(\mathrm{Mt})\end{array}$ \\
\hline 1990 & 8.54 & 5.95 & 15 & 13.2 & 7.8 \\
1991 & 10.10 & 6.54 & 16 & 13.1 & 5.8 \\
1992 & 10.48 & 7.20 & 17 & 14.1 & 5.8 \\
1993 & 10.96 & 7.54 & 18 & 14.2 & 6.2 \\
1995 & 12.34 & & 19 & 14.8 & 6.4 \\
1997 & 11.33 & 7.09 & 14 & 6.8 & 5.5 \\
1999 & 12.68 & 7.59 & 15 & 9.5 & 11.8 \\
\hline
\end{tabular}

It is clear that the pollution has been increasing with annual rates of $8.67 \%$ for the total waste gas and $8.21 \%$ for flue gas in China. For example, in 1999, the total waste gas from industrial production was up to 12,680 billion $\mathrm{m}^{3}$ and the flue gas from burning fossil fuels was over 7,590 billion $\mathrm{m}^{3}$, covering $59.9 \%$ of the total waste gas.

In China, caused from a great amount of coal burnt directly, as average values yearly, suspended particles in the air is up to $0.93 \mathrm{mg} / \mathrm{m}^{3} /$ day in cities in North areas and $0.41 \mathrm{mg} /$ $\mathrm{m}^{3} /$ day in cities in south areas; $\mathrm{SO}_{2}$ concentration in air is around $0.092 \mathrm{mg} / \mathrm{m}^{3} /$ day in cities in North areas and $0.088 \mathrm{mg} / \mathrm{m}^{3} /$ day in cities in south areas; and $\mathrm{No}_{\mathrm{x}}$ concentration in air goes to $0.054 \mathrm{mg} / \mathrm{m}^{3} /$ day in cities in North areas and $0.048 \mathrm{mg} / \mathrm{m}^{3} /$ day in cities in south areas.

In general, fossil fuels, like coal, oil and natural gas, are called as carbon-hydrogen energy from which waste gas emitted is mainly composed of $\mathrm{CO}_{2}$ that is a kind of greenhouse gas (GHG). It is estimated that the total $\mathrm{CO}_{2}$ emission from fossil fuels was 2,270 million tones in China, equalized to 620 million tones of carbon and contributed $11.8 \%$ of $\mathrm{CO}_{2}$ emission on the global GHG. Based on data in 1985, a prediction on the amount of $\mathrm{CO}_{2}$ emission from using fossil fuels in the next century has been made by a research group in China. The result is shown in the table 10 .

Table 10 Prediction for emission of $\mathrm{CO}_{2}$ from fiscal fuels in China

\begin{tabular}{|c|c|c|c|c|}
\hline Fossil fuel & \multicolumn{4}{|c|}{$\mathrm{CO}_{2}$ Emission $\left(10^{6} \mathrm{t}\right.$ carbon/year) } \\
\hline & 1985 & 1990 & 2020 & 2025 \\
Coal & 530 & 540 & $1,150 \sim 1,350$ & $1,670 \sim 1,940$ \\
Oil & 76 & 100 & $190 \sim 220$ & $320 \sim 370$ \\
Natural gas & 7 & 8 & $60-70$ & $90 \sim 110$ \\
Coal gas & 9 & 12 & $40 \sim 70$ & $70 \sim 80$ \\
Total & 622 & 660 & $\underline{1,570}^{*}$ & $2,220^{*}$ \\
\hline
\end{tabular}

* An average value.

By 2025, the annual $\mathrm{CO}_{2}$ emission will have gone up to 2,220 million tones of carbon, about 3.36 times as much as that in 1990 and 1.41 times as much as that in 2000. The increasing rate is $7.17 \%$ yearly. 
China government has paid a great attention on reducing its contribution of $\mathrm{CO}_{2}$ emission on the global GHG through ways as following:

- To improve energy efficiencies of fossil fuels for saving energy sources, reducing consumption of fossil fuels and controlling $\mathrm{CO}_{2}$ emission;

- To develop new and renewable energy, such as solar energy, wind energy, biomass energy, tide energy and nuclear energy for changing its energy consumption composition, that is, reducing consumption of fossil fuel, especially coal;

- To protect and develop forest resources, increase forest-cover rate, turn the land green with park and trees for speeding the absorption of $\mathrm{CO}_{2}$ and improving environment.

\section{Current Status and Future Prospects of Utilization of Agricultural and forestry}

\section{Residues and Other Biomass as Energy Source}

China is an agricultural country in which there are abundant biomass resources. From a theory estimation, its amount of biomass resources existing in cultivated lands, afforestated lands and prairies in the country may be over 5 billion tones in dry weight that is equal to $1.7 \times 10^{9}$ TOE. In fact, biomass resources available for energy mainly come from crop residues, firewood, forest wood residues and organic refuses, and the amount may be about $4.37 \times 10^{8}$ TOE. China has paid more attention on developing new technologies for utilizing effectively biomass as energy and will put these technologies into a popularized use in the next century.

\subsection{Availability of agricultural and forestry residues and other biomass}

In China, biomass resources that could be used as energy easily are mainly involved to four sources, i.e. crop residues, forest and wood residues, animal dung and organic refuses. Based on some related statistical data, an estimated amount of available biomass resources in the country will be calculated easily by simplified statistical ways.

\subsubsection{Crop residues}

In China, a great amount of crop residues can be produced from agricultural actions. According to statistical data (1994), in 1993, there are 95.1 million hectares of cultivated lands and 108 million hectares of undeveloped land in which there are 35.4 million hectares of useable land in this country. The total amount of grain products was 456.5 million tones, in which, the amount for rice, wheat and corn was 177.7, 106.4 and 102.7 million tones respectively.

a. Statistical method

The total biomass production of crop residues is related to amounts of crop-products, rates of residues produced from crops and heat values of residues. Thus, the amount of crop residues can be expressed by the following formula: 


$$
\widetilde{S}=\sum_{i=1}^{n} S_{i} \cdot d_{i}
$$

In which $\widetilde{S}$ means the total amount of biomass from crop residues in the country,

$S_{i}$ is the amount of grain produced from a special crop,

$d_{i}$ is the rate of residues biomass produced from the special crop,

And $i=1,2,3 \cdots \cdots \cdot \mathrm{n}$ for a special crop.

Table 11 Rate of Residues Produced from a Special Crop $(\mathrm{kg} / \mathrm{kg})$

\begin{tabular}{|c|c|c|c|c|c|c|c|c|c|c|}
\hline & Wheat & Rice & $\begin{array}{c}\text { Corn } \\
\text { Soybea } \\
\mathrm{n}\end{array}$ & Tuber & Sorghum & Millet & Cotton & oil-crop & Others \\
\hline $\begin{array}{c}\text { Rate of } \\
\text { residues }\end{array}$ & 1 & 1 & 2 & 1.5 & 1 & 2 & 1 & 3 & 2 & 1 \\
\hline
\end{tabular}

In case of the amount expressed as TOE of energy, the formula can be:

$$
\widetilde{E}=\sum_{i=1}^{n} \alpha_{i} \cdot S_{i} \cdot d_{i}
$$

in which $\bar{E}$ expresses the total biomass energy from crop residues in TOE, and $\alpha_{i}$ is the heat value at a low level $\left(\mathrm{LHV}_{\mathrm{i}}\right)$ of a special crop residue and it can be treated as a constant value $\left(\mathrm{LHV}_{\mathrm{o}}\right)$ in order to simplify calculations. Thus, the biomass energy can be expressed as:

$$
\tilde{E}=\boldsymbol{\alpha} \cdot \tilde{S}
$$

In case of crop residues, $\alpha$ may be $14,630 \mathrm{~kJ} / \mathrm{kg}$, because most of crop residues have their $\mathrm{LHV}_{\mathrm{i}}$ around $L H V_{\mathrm{o}}$, that is $\frac{L H V_{i}}{L H V_{o}} \approx 1$.

b. Results

In China, rice, corn and wheat are three kinds of main grain products, meanwhile, they are main biomass resources from agriculture production. In 1998, It is estimated that the total yield of residues was 772 million tones, equal to 270 million TOE of biomass energy, in which, about 200 million TOE was from residues of rice, corn and wheat, covering 74.3\% of total biomass energy from all crop residues in the country. Respectively, about 99.3 million TOE of biomass energy was contributed by rice residues covering $26 \%, 38.2$ million TOE by wheat residues covering 14\%, 93.1 million TOE by corn residues covering $34 \%$ and 71 million TOE by others covering 26\% (Fig.15).

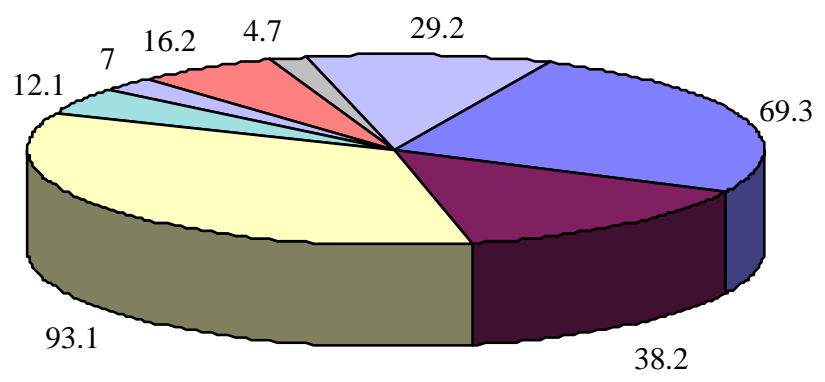

\begin{tabular}{|l|}
\hline Rice \\
$\square$ Wheat \\
$\square$ Corn \\
$\square$ Soybean \\
$\square$ Tuber \\
$\square$ Oil-crop \\
$\square$ Cotton \\
$\square$ Sugar Cane \\
\hline
\end{tabular}

Fig.15 Production of different crop residues in 1998(million TOE)

In 1998, approximately, only $10 \%$ of crop residues, about 80 million tones, was used as 
animal feeding, $20 \%$, about 150 million tones, as industrial materials, 52\%, 400 million tones, as fuels in rural areas and 18\%, 140 million tones, burnt or disused directly in farmlands.

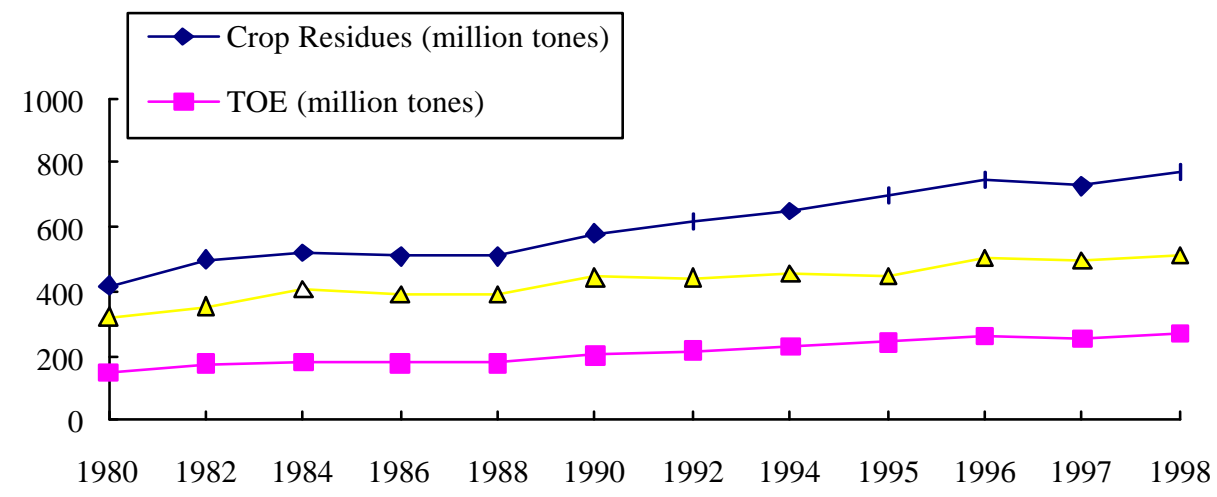

Fig. 16 Production of crop residues in China (1980-1998)

As development of economy in China, the yield of crop residues is still increasing at an increasing rate of $2.4 \%$ yearly in recent years (Fig.16). For example, in 1980, the biomass energy resource was 150 million TOES, and in1994, the amount was 216 million TOES, by 1998, the amount had become 270 million TOES. If the rate can be kept at a level of $1.5 \%$ in the first two decades of the next century, the biomass energy will have been 370 million TOE by 2020, and if the rate can be kept at a level of $1 \%$ at the next 30 years, 2020 2050, there will be 500 million TOE of biomass energy resources in the year of 2050 in China. This prediction is based on a fact that China has 148 million hectares of farmland for its agricultural production in 1993, but according to an update survey, the total area of farmland is up to 200 million hectares(1996). The total amount of crop biomass was only 1,200 million tones including about 600 million tones of agricultural products and about 600 million of crop residues. By a theoretical estimation, the total biomass production can be up to 3,000 million tones on the 200 million hectares of farmland, that is, the maximum biomass production from crop residues can be 1,500 million tones, equal to 525 million TOES.

\subsubsection{Firewood and forest residues}

In China, there are about 128.6 million hectares of forest area and a forest cover rate of $13.4 \%$. According to statistical data, the total amount of growing stock is about 10.8 billion cube meters. According to a survey of forest resources in 1989, China has about 4.44 million hectares of firewood forest occupied $3.72 \%$ of the total forest area in this year. In the national plan of planting trees, it is declared that China will plant 6.03 million hectares of firewood forest, that is, the area of Chinese firewood forest will have exceed 10 million hectares by 2001.

a. Statistical method

Because of the lack of further detail data, it is very difficult to calculate the yield of firewood and forest residues accurately. As we know, the yields of firewood and forest residues are variable to different forest types in different areas, depending on their productivity and collect ability. For example, the average yield of firewood forest can be over 7,500 kg/ha in south mountain area, but only $3,750 \mathrm{~kg} / \mathrm{ha}$ in North mountain area, while, that of shrub 
forest may be $750 \mathrm{~kg} / \mathrm{ha}$ in the country, but the collected coefficient is 0.5 in plains area, and 0.2 in mountain area.

The total biomass production of firewood and forestry residues is related to types of forests, areas of forests, amounts of trees inside and along side farmland and rates of biomass production in different forests and different areas. Thus, the amount can be expressed by the following formula:

$$
\widetilde{S}=\left[\sum_{i=1}^{n} \sum_{j=1}^{m} \eta_{i j}\left(A_{i j} \cdot r_{i j}+T_{i} \cdot d_{i}\right)\right]+1 / 3 W
$$

in which $\widetilde{S}$ means the total amount of biomass from firewood and forest residues in the country,

$A_{i j}$ means areas covered by different forests $(j)$ in different regions $(i)$,

$r_{i j}$ means rates of biomass produced from different forests $(j)$ in different regions $(i)$,

$\eta_{i j}$ means collectable coefficients of biomass from different forests $(j)$ in different regions $(i)$,

$T_{i}$ means amounts of trees inside and along side farmland are in different regions $(i)$

$d_{i}$ means rates of residues produced from trees inside and along side farmland in different regions $(i)$,

$i=1,2,3 \ldots . . . \mathrm{n}$, regions,

$j=1,2,3 \ldots . . \mathrm{m}$, types of forests.

Table 12 Rates of biomass from different forestry in different regions

\begin{tabular}{|c|c|c|c|c|c|c|}
\hline \multirow{2}{*}{$\begin{array}{c}\text { Regions } \\
\text { Types of forestry }\end{array}$} & \multicolumn{2}{|c|}{$\begin{array}{l}\text { Mountain Areas in } \\
\text { the South }\end{array}$} & \multicolumn{2}{|c|}{ Plain and Hills } & \multicolumn{2}{|c|}{$\begin{array}{c}\text { Mountain Areas in the } \\
\text { North }\end{array}$} \\
\hline & Ç & $\begin{array}{r}r \text { or } d \\
(\mathrm{~kg} / \mathrm{ha} .)\end{array}$ & Ç & $\begin{array}{r}r \text { or } d \\
(\mathrm{~kg} / \mathrm{ha} .)\end{array}$ & Ç & $\begin{array}{r}r \text { or } d \\
(\mathrm{~kg} / \mathrm{ha} .)\end{array}$ \\
\hline Firewood forestry & 1.0 & 7,500 & 1 . & 7,500 & 1.0 & 3,750 \\
\hline Protection forestry & 0.2 & 750 & 0.5 & 750 & 0.2 & 750 \\
\hline Shrub forestry & 0.5 & 750 & 0.7 & 750 & 0.3 & 750 \\
\hline Depleted forestry & 0.5 & 1,200 & 0.7 & 1,200 & 0.3 & 1,200 \\
\hline $\begin{array}{l}\text { Trees inside and along } \\
\text { side farmland }\end{array}$ & 1.0 & $2 \mathrm{~kg} /$ tree & 1.0 & $2 \mathrm{~kg} /$ tree & 1.0 & $2 \mathrm{~kg} /$ tree \\
\hline
\end{tabular}

In case of the amount expressed as TOE of energy, the formula can be revised as following: $\bar{E}=\alpha \cdot \tilde{S}$

in which $\bar{E}$ expresses the total biomass energy from firewood and forest residues in TOE, and $\alpha$ is a constant value and expresses an average heat value at low level $\left(\mathrm{LHV}_{\mathrm{o}}\right), 18,000$ $\mathrm{kJ} / \mathrm{kg}$ for crop residues, because most of these biomass fuels have their $\mathrm{LHV}_{i}$ around $\mathrm{LHV}_{\mathrm{o}}$ , that is $\frac{L H V_{i}}{L H V_{o}} \approx 1$.

b. Results

There is no official statistical data in hand for recent years, therefore, all works on calculation on firewood biomass is based on statistical data provided by Ministry of Forest Industry (MOFI) in 1994, it is estimated that the yearly yield of firewood may be over 120 million tones in 1993, or equal to 52 million TOEs (Fig.17). 


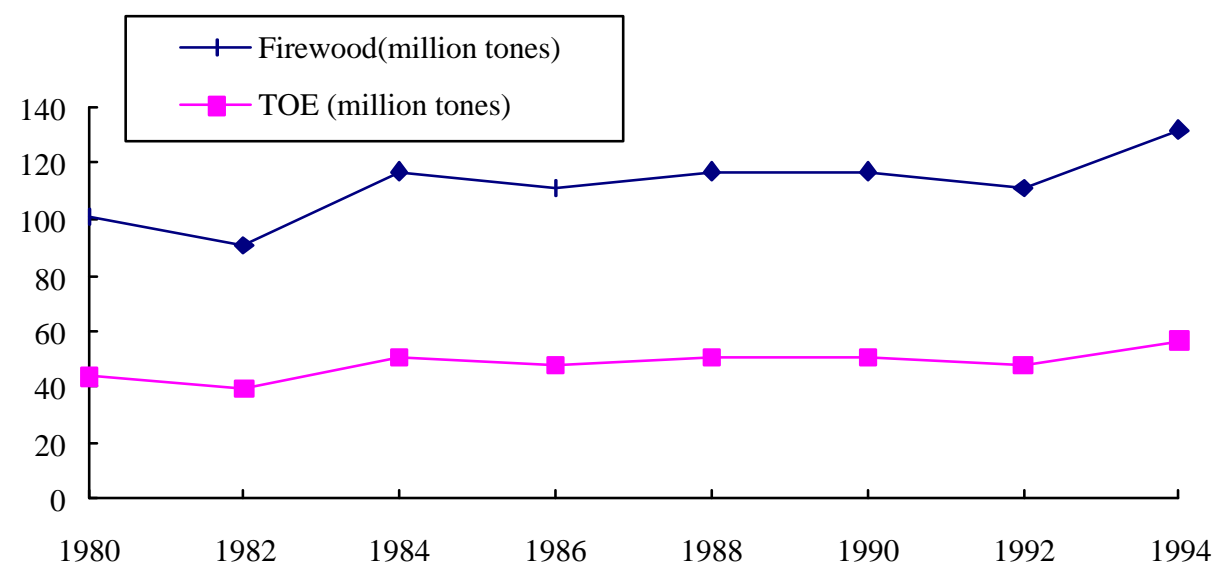

Fig.17 Production of firewood in China in several years

From Fig.17, we can see that there is a little increasing of firewood production. But, it must be remembered that this estimation is made as a rational supply amount in theory, and in fact, the amount of firewood consumption is beyond these figures much, the shortage comes from over-cutting forest trees. In fact, the total consumption of firewood and forest residues was about 64 million TOEs in 1993 that was reported by the MOFI.

\subsubsection{Dung}

Dung or manure is an important biomass resources and its year yield of manure is concerned to the population and livestock production in a country. In 1999, Chinese population was up to 1.26 billion, the numbers of livestock fed in farms was: large animals 150 million heads including houses, cattle, donkeys, mules and camels; hogs 520 million heads; sheep and goats 279 million heads; the poultry 5.28 billion heads in 1999 .

a. Statistical method

The total animal dung biomass is related to the size of population in the country, Animal husbandry production and rates of dung excreted from different individuals. Thus, the amount can be expressed by the following formula:

$$
\tilde{S}=\sum_{i=1}^{n} \eta_{i} \cdot d_{i} \cdot M_{i}
$$

in which $\widetilde{S}$ means the total amount of biomass from animal dung in the country in the dry weight,

$M_{i}$ means sizes of population in the country or different groups $(i)$ of husbandry animal, $\eta_{i}$ means rates of animal dung excreted by individuals from different groups $(i)$, $d_{i}$ means age coefficients of individuals in different groups, and $i=1,2,3 \cdots \cdots \cdot \mathrm{n}$.

Table 13 Rate of dung excreted by different individuals in different groups

\begin{tabular}{|c|c|c|c|c|c|c|}
\hline Items & Human being & Pig & Cattle & Horse & $\begin{array}{c}\text { Goat/shee } \\
\mathrm{p}\end{array}$ & Poultry \\
\hline$\eta_{i}$ (kg/ones/yr, dry weight $)$ & 33 & 300 & 1,000 & 750 & 150 & 5 \\
$d_{i}$ & 0.9 & 0.8 & 0.7 & 0.7 & 0.8 & 0.9 \\
\hline
\end{tabular}


In case of the amount expressed as TOE of energy, the formula can be:

$$
\bar{E}=\alpha \cdot \tilde{S}
$$

in which $\bar{E}$ expresses the total biomass energy from animal dung in TOE, and $\alpha$ is a constant value and expresses an average heat value at low level $\left(\mathrm{LHV}_{\mathrm{o}}\right), 14,000$ $\mathrm{kJ} / \mathrm{kg}$ for animal dung, because their $\mathrm{LHV}_{i}$ is around $\mathrm{LHV}_{\mathrm{o}}$, that is $\frac{L H V_{i}}{L H V_{o}} \approx 1$.

b. Results

Based on the data mentioned above and excretion rates of animal dung (table 13), it may be estimated that the biomass resource from the dung residue might be up to 299 million tones in dry weight, about 103 million of TOE in 1999. In Fig.18, it is shown that the yield had of firewood and forest residues has been increased in recent years as the development of livestock production in the country.

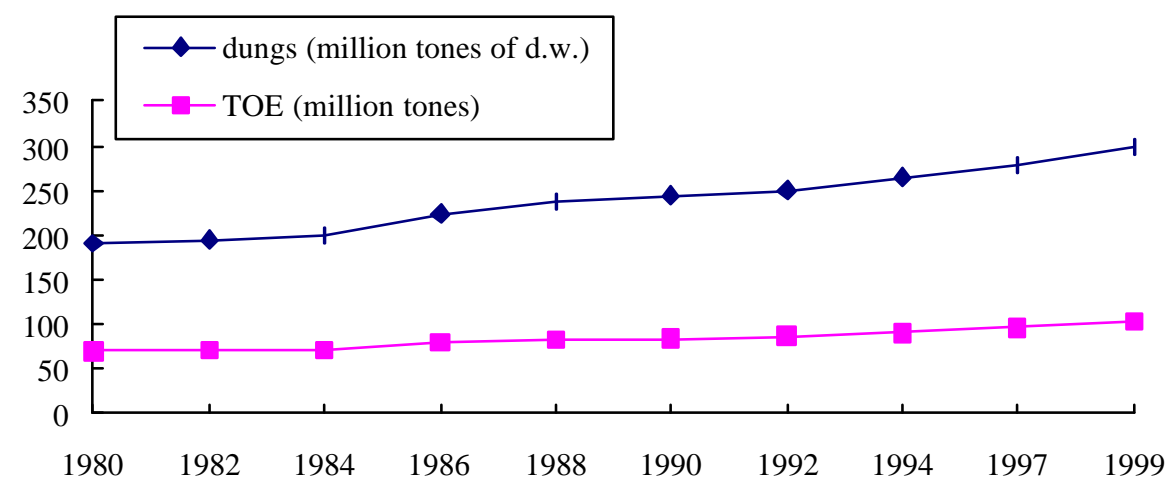

Fig. 18 Biomass from animal dung (1980-1999)

However, there is a small amount of animal dung used as energy in China. The first use is the direct burning animal dung as energy occurred only in minority areas, such as Tibet, Qinghai and Ningxia, where a heavily shortage of energy sources and the amount might be 10 million tones. Secondly, there are some amount of animal dung has been used as materials for household biogas digester in rural areas, and the amount might be 7 million tones in dry weight.

\subsubsection{Others}

Others of biomass resources include wastewaters from distillery, paper, sugar and food industry production, solid organic wastes from daily life and agricultural industry, and waste water from daily life. In a statistics based on data of 1990 for 230 cities in China, it is shown that about 6 billion tones of waste water containing a high concentration of organic matter was drained from distillery, paper, sugar and food processing, in which, about 2.5 million tones of COD accounted for $33.2 \%$ of total amount of 7.2 million tones COD discharged from industrial production in the country. In addition, about 53 million tones of wastewater and 2.5 million tones of solid wastes were excreted daily from daily life in these cities in the same year.

It is estimated that the total annual yield of biomass contained in these solid wastes may be up to 92 million tones of TOE in cities of the country. By now, the amount have been 
increasing yearly at $8 \%$ of growing rate, but there is a little amount of these refuses being used as energy.

\subsubsection{Total production of biomass yearly}

Overlooking some small biomass resources, like waste water and industrial solid wastes, only from four resources, such as crop residues, firewood, animal dung and solid wastes from daily life, a great amount of biomass can be used as energy sources, about 520 million tones of TOEs (Fig.19). From Fig.19, it can be seen that the crop residue is the biggest biomass resource, covering about $52 \%$ of the total biomass resource in the country. In 1999, about 140 million TOE of biomass was used as energy, covering $27 \%$ of the total amount of biomass resources in the country.

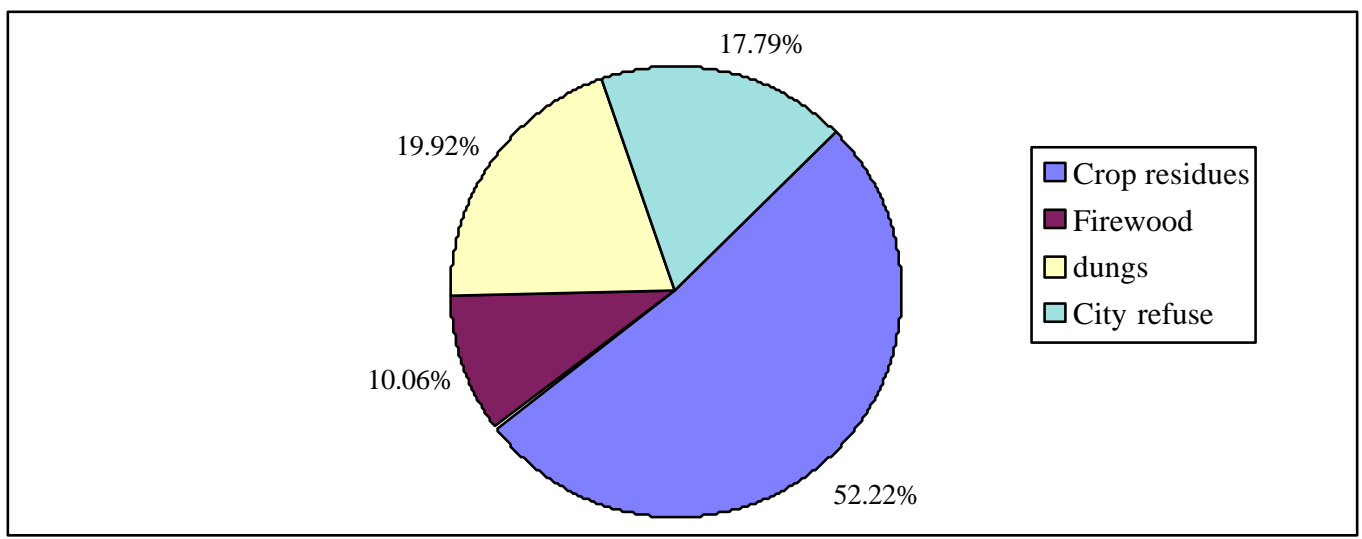

Fig. 19 The Constitute of biomass from different sources in China (1999)

\subsubsection{Biomass distribution in China}

Being different from other energy sources, biomass resource has some characters that should be considered carefully for selecting ways of using it as energy. These characters are shown as following:

- a renewable and hug natural resource;

- low sulphur, <01\%, and low ash, $<15 \%$;

- low energy density, $300 \sim 700 \mathrm{~kg} / \mathrm{m}^{3}$ or $4.2 \sim 12.6 \mathrm{GJ} / \mathrm{m}^{3}$;

- low heat value, $14,000 \sim 18,000 \mathrm{~kJ} / \mathrm{kg}$;

- high water content, 5 20\%.

- uneven distribution in different areas;

- difficult for collection and transportation;

- low per capital resource, about $0.36 \mathrm{TOE} /$ person.

By its utilization as energy, not only a lot of fossil fuels will be saved, but also a great of benefits on environment improvement will be obtained. Of course, its distribution should be considered for collecting and transporting biomass materials easily in order to conduct such a project successfully. Table 13 shows the distribution situation of biomass resources in China. 
Table 14. Contribution Densities* of Biomass in Different Areas

\begin{tabular}{|c|c|c|c|}
\hline Areas & Crop residues & Dung** & Firewood \\
\hline Northeast & ++++ & ++ & ++++ \\
Inner Mongolia & ++ & ++++ & + \\
Huangtu Mountain & ++ & + & + \\
End-middle of the Yongze & +++ & + & ++ \\
Southwest & + & ++ & +++ \\
South of China & ++ & + & +++ \\
Ganshu-Xinjiang & +++ & ++++ & + \\
Qinghai-Tibet & + & ++++ & + \\
\hline
\end{tabular}

* biomass distribution is expressed by degrees of comparing the annual yield of biomass with rural population in a given area, that is, the unit is $\mathrm{kg}$ biomass/year/per capita.

a. Crop residues $(+)<500,(++) 500 \sim 525,(+++) 625 \sim 750,(++++)>750$;

b. Animal Manure $(+)<200,(++) 200 \sim 300,(+++) 300 \sim 500,(++++)>500$;

c. Firewood : $(+)<100,(++)$ 100 200, $(+++)$ 200 300, $(++++)>400$.

** not including human manure resource in cities

In the northeast area and the end-middle of the Yongze River, crop biomass resources are more abundant than other areas; in the Inner Mongolia area, the Ganshu-xingjang area and Qinghai-Tibet area, the most plentiful biomass resource comes from animal dung; and the firewood and forest residues are mainly distributed in the northeast area, the southwest area and south area.

\subsection{Current status of biomass energy conversion technologies}

Traditionally, biomass is a major energy source in China, especially in its rural areas. Crop and forest residues are two sources of biomass and mainly used as fuels for cooking food and/or warming room by a way of direct burning.

In 1979, there was a serious shortage of energy occurred in Chinese rural areas. The total energy consumption only 224 million TOE. Even though about $83.4 \%$ of rural energy was used as living energy, but about $47 \%$ of rural families still fallen into dire straits of lacking energy for 3 6 months per year. In order to resolve this problem, China government put the development of biomass energy utilization technology into the 6th Five Year Plan (19811985) and the 7th Five Year Plan (1986-1990). Since that time, China had begun to develop its biomass resources and energy conversion technology. Up to 1990, about 2.8 million hectares of firewood forest had been planted, 5 million sets of household biogas digesters had been built and operated, and a great amount of saving-fuel stoves had been used by 110 million of rural families.

Since 1991, the development of rural economy has brought a new problem that rural residents have begun to disuse their traditional fuel — biomass, but prefer to use convenient and clean fuels, such as coal and liquefied natural gas, because direct burning biomass fuels is less efficient, labored and too dirty. Thus, most of crop residues had to be burnt directly in cultivated land in order to reduce works on transportation and stockpile of these residues.

So, China has paid more attention on developing new technologies to convert biomass into 
convenient and clean energy products, such as low or middle energy gas fuel, biogas, briquetting fuel and liquid fuel, in the period of the 8th Five Year Plan (1991-1995). During the 9th Five Year Plan (1996-2000) and the first decade of the next century, China will continue to develop its biomass energy conversion technologies and put more and more financial investment to support conduction of priority projects in this fields.

\subsubsection{Biomass energy conversion technologies and their relation}

These new technologies developed in China are involved in:

- anaerobic digestion, including household digester and industrial anaerobic system, for treating animal manure, waste water to produce biogas;

- thermal pyrolysis, including gasification, liquefaction and carbonization, for treating crop and/or forest residues, industry organic wastes to produce gas fuel, bio-diesel and coke fuel;

- alcohol process for treating lingo-cellulose-wastes to produce ethanol fuel;

- briquetting process for identifying incompact biomass materials;

- efficient burning furnace and saving fuel stoves.

These new energy products and their final uses are shown as following:

- biogas: cooking by independent users or centralized gas supply nets, electricity generation or boiler fuels in factories.

- low energy gas: cooking by independent users or centralized gas supply nets, drying wood or other products in factories, electricity generation;

- middle energy gas: cooking by independent users or centralized gas supply nets, drying wood or other products in factories, electricity generation or synthesize liquid fuels, like methanol;

- bio-diesel: driving engines;

- alcohol: driving engines;

- briquetting fuel: cooking by direct burning in a special stove, pyrolysis for producing charcoal, gas fuel and bio-oil;

- hot air: drying processes in factories.

These technologies, energy products and their final uses are shown in the fig. 20 . 


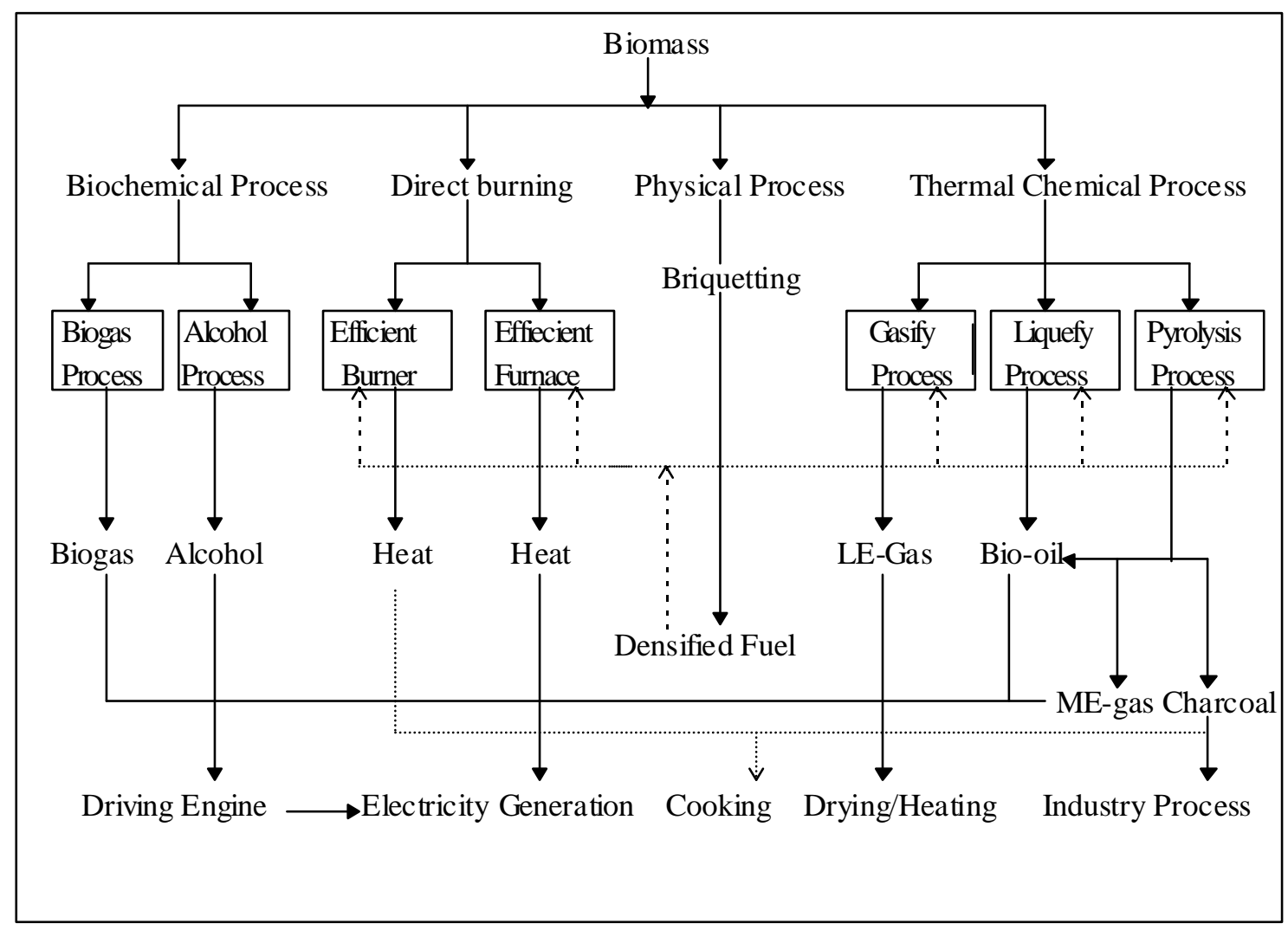

Fig.20 Biomass energy conversion technologies and their relations

\subsubsection{Status of biomass energy conversion or utilization technologies}

\section{a. Biogas}

The technology has been developed for 20 years in China. By now, the technology has been improved greatly and used widely in the country. For example, some new household digesters have been improved to be more efficient and more convenient, to get more biogas and to put smaller investment comparing old ones. The biogas production efficiency of old digester is only $0.1 \mathrm{~m}^{3} / \mathrm{m}^{3} . \mathrm{d}$, but that of these new digesters can be between 0.2 and 0.4 $\mathrm{m}^{3} / \mathrm{m}^{3}$.d. Another example is anaerobic technology that many kinds of processes have been developed in China, such as mixing reactor, filter reactor, sludge bed reactor and fixed bed reactor. These reactors have been used widely for treating waste-water from food processing, fermentation processing, sugar fining and daily life, and animal dung from pig farms, cow farms and chicken farms. Their biogas conversion efficiencies can be varied from 0.5 to $6.9 \mathrm{~m}^{3} / \mathrm{m}^{3}$.d and rates of COD removed can be in range from $70 \%$ to $86 \%$.

\section{b. Gasification}

In recent years, the gasification technology has got a great progress in China. Three processes have been developed for treating different materials and different usage. First one is the up-draught fixed bed gasifier. Its gasifying efficiency is $75 \%$ and maximum energy output is about $1,400 \mathrm{MJ} / \mathrm{h}$. The system can convert crop residues into gas fuel and one system can provide $800 \mathrm{~m}^{3}$ of gas fuel to 90 rural families daily by a gas supply net. Second one is the downdraught fixed bed gasifier. Its gasifying efficiency is over $75 \%$ and maximum energy output is $620 \mathrm{MJ} / \mathrm{h}$. The system is mainly used for treating wood wastes and supplying $2600 \mathrm{~m}^{3}$ of gas fuel to wood drying process in a factory. Third one is down 
draught recycle fluid bed gasifier. Its gasifying efficiency also is $75 \%$ but its maximum energy output is up to $2,900 \mathrm{MJ} / \mathrm{h}$. The system has been operated successfully for treating wood powder and providing gas fuel in a factory.

\section{c. Pyrolysis}

Being undertaken a pyrolysis process, many kinds of biomass materials can be convert into three kinds of energy products: fuel gas, charcoal and bio-oil. By controlling reaction conditions, such as temperature, pressure and detained time in the reactor, we can change the proportion between the three products. In a typed process, $200 \sim 250 \mathrm{~m}^{3}$ of gas fuel, $250 \sim 600 \mathrm{~kg}$ of charcoal and 200 300 kg of bio-oil can be produced respectively.

\section{d. Briquetting}

There are two kinds of briquetting processes being researched: one is screw pressing and another is piston ramming. The first one has been developed for 10 years and used in a small scale, about 600 sets of briquetting machines in operation in China. Presently, a research group in the Liaoning Institute of Energy Resources has resolved the key technological problem in the screw pressing process, that is, a new screw head has been made of a special material. The screw head has a long service life owing to its property of wear resisting, up to 500 hours. The second one is still at a research stage.

\section{e. Others}

Several research groups in China have researched some new technologies, such as biomass liquefaction by thermal-chemical processes and alcohol from sugar or cellulose materials. These technologies are still at a research stage.

\subsubsection{Application of biomass energy conversion or utilization technologies}

By 1998, a great achievement has been made by China on biomass as energy, especially on biogas technology, the application result is so good that the total energy production has arrived at 1.15 million TOE, providing $0.24 \%$ of the total rural energy (table 6). The second is the technology of improved stove and heat bed, about 0.525 million TOES saved yearly.

As shown in table 15, some new technologies have been developed in recent year and put them into a small scale of application. For example, about 700 sets of gasifiers have been operated for cooking by independent users or by centralized gas supply nets, wood drying processes and electricity generations; and about 800 sets of briquetting machines have been stalled for treating rice husks or stalks in the country. The total biomass energy output by these new technologies has been up to 1.77 million TOES.

Table 15 Application of biomass energy utilization technologies in China

\begin{tabular}{|l|l|l|l|l|}
\hline \multicolumn{1}{|c|}{ Technology } & \multicolumn{1}{|c|}{ Scales } & \multicolumn{1}{c|}{ Energy Production } & \multicolumn{1}{c|}{ TOE } & Note \\
\hline a. Biogas & & $2090{\text { million } \mathrm{m}^{3}}^{2}$ & $1,149,000$ & \\
Household digester & $6,884,000$ sets & 1,984 million $\mathrm{m}^{3}$ & $1,091,000$ & \\
Industrial digest system & 753 stations & 106 million $\mathrm{m}^{3}$ & 58,000 &
\end{tabular}




\begin{tabular}{|l|l|l|l|l|} 
bomestic sewage digester & 49,322 sets & & \\
Efficient furnace & Direct burning & efficiency $80 \%$ & 4,000 & energy saving \\
Improved stove/heat-bed & 184.7 millions & efficiency $25 \%$ & 525,000 & energy saving \\
c. Gasification & 684 sets & & 23,000 & \\
cooking by supply nets & 164 sets & 45.7 million $\mathrm{m}^{3}$ & 5,600 & 330 working days \\
wood drying & 370 sets & $560 \times 10^{9} \mathrm{~kJ}$ & 13,400 & 330 working days \\
electricity generation & 150 sets & $15 \mathrm{Gwh}$ & 4,000 & 5 MW(capacity) \\
d. Briquetting & 800 sets & 200,000 tones & 70,000 & 300 working days \\
Total & & $1,771,000$ & \\
\hline
\end{tabular}

\subsubsection{Manufacturers}

Under a strong support of the government, many bases or factories have been set up in recent years. It is estimated that there are more than 200 factories or enterprises that is working on manufacture of equipment and facilities for utilizing biomass as energy. At here, only a small part of them can be listed in the table 16 .

Table 16 List of manufacturers of equipment and facilities

\begin{tabular}{|l|l|l|}
\hline \multicolumn{1}{|c|}{ Manufacturers } & \multicolumn{1}{|c|}{$\begin{array}{l}\text { Equipment } \\
\text { /facilities }\end{array}$} & \multicolumn{1}{c|}{$\begin{array}{l}\text { Location } \\
\text { Areas }\end{array}$} \\
\hline Shunsheng Gasifier and Heat Supply Equip. Factory & Gasifier \\
Huairou Gasification Equipment Manufacturer & Gasifier \\
Liaoning Energy Resources Co. Ltd. & Gasifier/briquetting & Beijing \\
Beijing Tonghai New Energy Co. Ltd. & RM-PVC biogas & $\begin{array}{l}\text { Beijing } \\
\text { Liaoning }\end{array}$ \\
Beijing Green Globe Energy Co. Ltd. & Gasifier/biogas project & Beijing \\
Hangzhou Energy and Environment Co. Ltd. & Biogas project & Beijing \\
Shanghai East New Energy Co. Ltd. & Biogas project \\
Shanghai Three Stars Energy \& Environment CO. Ltd. & Biogas project \\
Botou New Energy Service Co. Ltd. & Biogas project \\
Shijiazhuang Huadu Energy \& Environment Co. Ltd. & Briquetg. machine/gasifier \\
Yingkou Plastics Auxiliary Factory & RM-PVC biogas & Shanghai \\
Yiyang Biomass Fuel Co. Ltd. & Pyrolysis & Shanghai \\
Nanyang Alcohol General Plant & Biogas project \\
Yunnan Environment \& Energy Co. Ltd. & Briquetting machine \\
Wugong Light Industry Machine Factory & Briquetting machine \\
Lanzhou Keneng Co. Ltd. & Briquetting machine \\
Beijing Suntrip Solar Energy Co. Ltd. & Biogas project \\
Lianyungang Light Industry Machine Factory & Briquetting machine \\
Dalian Energy \& Environment Co. Ltd. & Pyrolysis & Hunan \\
henan \\
Yunnan \\
Shanxi \\
Ganshu \\
Beijing \\
Jiangshu \\
Liaoning \\
\hline
\end{tabular}




\subsection{Past and ongoing efforts of the government and universities and other private research institutes/organizations}

It is well known; China is the biggest developing couture in the world, about $75 \%$ of its population, more than 880 million (1999) in rural area. Traditionally, biomass, such as crop residues and firewood, is the most important part of the rural energy. Due to being utilized directly on fire, biomass is treated as a kind of inconvenient energy source, low efficiency (about 10\%), labored and dirty. So China does its best to develop the biomass energy technology for meeting its energy demand.

\subsubsection{Government activities}

As the development of national economy, China government has been putting a great attention on utilization of biomass as energy through developing new technology for long time. In past four successive national plans, $6^{\text {th }}, 7^{\text {th }}, 8^{\text {th }}$ and $9^{\text {th }}$ "Five-year Plan" (1980200), biomass energy technology had been playing an important role in the issue of renewable energy developments.

By hard works on biomass energy in the period of the last 20 years, an integrated management, development and research system net has been set up between the government, institutes/ universities, manufacturers /users in China. The system net has been and will be operated to speed the development and popularization of the technology in the country. The relations of members in the net are shown as following:

- $\mathrm{MOST} \rightarrow \mathrm{CAS}, \mathrm{SEC}, \mathrm{CBDC}$, local STC $\rightarrow$ institutes /universities
for developing technology

- $\mathrm{SPC} \rightarrow$ Ministries of agriculture, forestry, electricity and other related $\rightarrow$ CAS, $\$ E C$, local STC or REO $\rightarrow$ institutes /universities to set up bases for technology demonstrations

- $\quad$ SETC $\rightarrow$ Ministries of agriculture, forestry, electricity and other related $\rightarrow$ CAS, SEC, local STC $\rightarrow$ institutes/universities $\rightarrow$ manufacturers/users for technology popularization

In which, MOST is the Ministry of Science and Technology, SPC is the State Planning Commission, SETC is the State Economy \& Trade Commission, CAS is Chinese Academy of Science, SEC is the State Education Commission, local STC is local science \& technology commissions, CBDC is the China Biomass Development Center and local REO is local rural energy offices.

In the past 20 years, the net has put more attention on developing biomass energy and made a great achievement on putting the technology into a wide use, as mentioned in Part 2.2.2. Some excellent demonstration projects have been built up and operated successfully in the country and many institutes, universities and organizations have been involved in conducting these projects in national plans, by which, a big benefit has been obtained on popularizing biomass energy technologies, utilizing biomass energy efficiently and protecting environment.

Now, Chinese Government is drawing its $10^{\text {th }}$ “ Five-year Plan”, in which the biomass 
energy development will be an important issue in the area of renewable energy.

\subsection{2 demonstration projects}

In past four successive national plans, $6^{\text {th }}, 7^{\text {th }}, 8^{\text {th }}$ and $9^{\text {th } ~ " ~ F i v e-y e a r ~ P l a n " ~}(1980-2000)$, biomass energy technology had been playing an important role in the issue of renewable energy developments. Some excellent demonstration projects have been built up and operated successfully in the country.

Table 17 List of biomass energy projects typed in China

\begin{tabular}{|l|l|c|c|l|l|}
\hline \multicolumn{1}{|c|}{ Projects } & Materials & Scales & Capacities & Usage & Locations \\
\hline a. Biogas projects & & $\mathrm{m}^{3}$ & $\mathrm{~m} / \mathrm{d}$ & & \\
Fushan Chicken Farm(UASB) & dung & 700 & 720 & cooking & Zhejiang \\
Botou Distillery (UFB) & distilled waste & 2,000 & 2,400 & & Hebei \\
Ziyang Sugar Refinery & distilled waste & 1,400 & 4,000 & & Henan \\
Huabei Pharmacy Plant & waste water & 6,000 & 4,000 & & Hebei \\
Huian Chemical Works & waste water & 10,800 & 7,040 & & Fujian \\
Lezhi Distillery & distilled waste & 600 & 3,600 & & Sichuan \\
Xinghuo Biogas Station & dung & 2,700 & 2,700 & cooking & Shanghai \\
Nanyang Distillery & distilled waste & 10,000 & 40,000 & cooking & Henan \\
Huian Chemical Plant Biogas Station & waste water & 10,800 & 10,800 & cooking & Shanxi \\
b. Gasification projects & & & & & \\
Huairou Wood Equip. Drying System & sawdust & ND600 & $620 \mathrm{MJ} / \mathrm{h}$ & wood dry & Beijing \\
Huantai Integrate Gas-supply System & crop residues & $\mathrm{XLF}$ & $1,400 \mathrm{MJ} / \mathrm{h}$ & cooking & Shangdong \\
Shanya CFB Gasifier System & wood powder & $\mathrm{CFB}$ & $2,900 \mathrm{MJ} / \mathrm{h}$ & cooking & Hainan \\
c. Pyrolysis Projects & & & & & \\
Dalian Biomass Pyrolysis Gas System & wood residues & & $1,000 \mathrm{houses}$ & cooking & Liaoning \\
Butoujiang Biomass Pyrolysis System & wood residues & & & charcoal & Hunan \\
d. Briquetting projects & rice husks & & $1,000 \mathrm{t} / \mathrm{y}$ & solid fuel & Jiangshu \\
Jurong Briquette Fuel Producing Line & & & $1,000 \mathrm{t} / \mathrm{y}$ & solid fuel & Shanxi \\
Wugong Grain Machine factory Line & rice husks & & & \\
\hline
\end{tabular}

\subsubsection{Institutes, universities and organizations}

In 1987, the State Science and Technology Commission in Liaoning Province set up the China Biomass Development Center. The center is in charge of doing affairs related to development of biomass energy in the country, such as managing national projects, making national plans, conducting academic exchanges and cooperation between China and international institutes or organizations, and organizing and coordinating programs of research and development. Table 18 shows the members of the Center, including some institutes, universities and organizations involved in biomass energy.

Table 18 Members of China Biomass Development Center 


\begin{tabular}{|c|c|c|c|}
\hline 1. & China Biomass Development Center & all fields of biomass & Beijing \\
\hline 2. & Beijing Solar Energy Institute & biogas liquefaction & Beijing \\
\hline 3. & Liaoning Institute of Energy Resources & biogas Igasifierlbriquett. & Yingkou \\
\hline 4. & Shandong Institute of Energy Resources & gasifierlbiogas & Shanghai \\
\hline 5. & Zhejiang Institute of Energy Resources & biogas & Hangzhou \\
\hline 6. & Jilin Institute of Energy Resources & biogas & Changchun \\
\hline 7. & Qinghai New Energy Institute & biogas & Xining \\
\hline 8. & Institute of Energy Resources of Hebei Academy of Science & gasifierlbriquetting & Shijiazhuang \\
\hline 9. & Institute of Energy Resources of Jiangxi Academy of Science & biogas & Wuhan \\
\hline 10. & Chengdu Institute of Biology, Chinese Academy of Science & biogas & Chengdu \\
\hline 11. & $\begin{array}{l}\text { Institute of Engineering Thermo-physics, Chinese Academy } \\
\text { of Science }\end{array}$ & gasifier & Beijing \\
\hline 12. & Guangzhou Energy Institute, Chinese Academy of Science & biogas $\backslash$ gasifier & Guangzhou \\
\hline 13. & $\begin{array}{l}\text { Institute of Energy and Environment Protection, Chinese } \\
\text { Academy of Agri-Engineering Research and Planing }\end{array}$ & biogaslfurnace & Beijing \\
\hline 14. & $\begin{array}{l}\text { Energy and Power Research Institute, Chinese Academy of } \\
\text { Agri-Mechanization Science }\end{array}$ & Gasifierlbriquetting & Beijing \\
\hline 15. & $\begin{array}{l}\text { Environment Science Research Institute of Shanghai Academy } \\
\text { of Agri-science }\end{array}$ & biogas & Shanghai \\
\hline 16. & $\begin{array}{l}\text { Research Institute of Chemical Processing and Utilization of } \\
\text { Forest Products }\end{array}$ & gasifierlbriquetting & Nanjing \\
\hline 17. & $\begin{array}{l}\text { Chengdu Biogas Scientific Research Institute of the Ministry } \\
\text { Agriculture }\end{array}$ & biogas & Chengdu \\
\hline 18. & Renewable Energy Institute, Capital Normal University & biogas microbiology & Beijing \\
\hline 19. & $\begin{array}{l}\text { Department Chemical Engineering for Energy Resources, East } \\
\text { China University of Science \& Technology }\end{array}$ & alcohol from cellulose & Shanghai \\
\hline 20. & Shanghai Institute of Industrial Microbiology & biogas & Shanghai \\
\hline 21. & Technology R\&D Institute of Jiangshu Province & biogas $\backslash$ briquetting & Wujin \\
\hline 22. & Institute of Microbiology, Shangdong University & biogas microbiology & Jinan \\
\hline 23. & $\begin{array}{l}\text { Microbiology Laboratory, Department of Environmental } \\
\text { Science, Zhejiang Agricultural University }\end{array}$ & biogas microbiology & Hangzhou \\
\hline 24. & Institute of New Technology of Changsha & gasifier & Changsha \\
\hline 25. & Solar Energy Research Institute, Yunnan Normal University & briquetting & Kunming \\
\hline 26. & $\begin{array}{l}\text { Energy \& Environ. Enginrg. Research Department, College of } \\
\text { Agri-Enginrg. for Shenyang Agri- University }\end{array}$ & $\begin{array}{l}\text { alcohol from sugar } \\
\text { materials liquefaction }\end{array}$ & Shenyang \\
\hline
\end{tabular}




\subsubsection{The $9^{\text {th }}$ Five Year Plan}

From 1995 to 2000 , the $9^{\text {th }}$ five-year Plan had been conducted by MOST, in which the biomass energy technology was put on an important place. By 2000, most of these research works had been finished and a great achievement had been made (Table 19).

Table 19 Research results on biomass energy in "the 9th Five-year Plan"

\begin{tabular}{|c|c|c|c|}
\hline Projects & Scales & Institutes & Location \\
\hline $\begin{array}{l}\text { 1. Gasification } \\
\text { - An integrated system for } \\
\text { converting crop residues to } \\
\text { energy sources } \\
\text { - } 1.0 \mathrm{MW} \text { electricity generation } \\
\text { system by biomass gasification } \\
\text { Integrated gas supply systems } \\
\text { by crop residues gasification }\end{array}$ & $\begin{array}{l}480 \text { Mwh, } 1,500 \text { tones } \\
\text { briquette fuel, } 300 \text { tones } \\
\text { charcoal yearly } \\
3,000 \text { Mwh electricity yearly } \\
\begin{array}{l}500, \quad 1,000 \text { and } 3,000 \\
\text { households }\end{array}\end{array}$ & $\begin{array}{l}\text { Liaoning Institute of Energy } \\
\text { Resources } \\
\text { Guangzhou Energy Institute of } \\
\text { CAS } \\
\text { 1. Shandong Institute of } \\
\text { Energy Resources } \\
\text { 2. Dalian Institute of Energy \& } \\
\text { Environment } \\
\text { 3. Nanjing Institute of Forest } \\
\text { Chemical Products }\end{array}$ & $\begin{array}{l}\text { Yingkou } \\
\text { Guangdong } \\
\text { Shandong } \\
\text { Dalian } \\
\text { Shuzhou }\end{array}$ \\
\hline $\begin{array}{l}\text { 2. Biogas } \\
\text { - A large anaerobic system for } \\
\text { treating pig dung } \\
\text { A anaerobic system for } \\
\text { treating city refuses }\end{array}$ & $\begin{array}{l}10,000 \mathrm{~m}^{3} \text { biogas daily } \\
100 \text { tones refuses treated } \\
\text { daily }\end{array}$ & $\begin{array}{l}\text { Shanghai Institute of Industrial } \\
\text { Microbiology } \\
\text { Chengdu Institute of Biology } \\
\text { of CAS }\end{array}$ & $\begin{array}{l}\text { Shanghai } \\
\text { Mianyang }\end{array}$ \\
\hline $\begin{array}{l}\text { 3. Liquid fuels } \\
\text { - A pilot alcohol system from } \\
\text { cellulose materials } \\
\text { - A research work on plant oil as } \\
\text { energy }\end{array}$ & $\begin{array}{l}2 \text { tones materials be treated } \\
\text { daily } \\
10 \text { hectares of oil-forest for } \\
\text { demonstration }\end{array}$ & $\begin{array}{l}\text { East China Science and } \\
\text { Technology University } \\
\text { Changsha Institute of New } \\
\text { Technology }\end{array}$ & $\begin{array}{l}\text { Wuhan } \\
\text { Changsha }\end{array}$ \\
\hline
\end{tabular}

\subsection{Future prospects for use of biomass energy source}

\subsection{1 the Agenda 21 of China}

In 1992, just after the 92' UN Environment and Development Conference, the government cleared that " clean energy sources, such as solar, wind, geothermal, tidal and biomass, should be exploited and utilized based on local conditions".

In "the Agenda 21 of China" issued by the Management Center of "the Agenda 21 of China" in 1995, some biomass energy projects are confirmed as " national priority projects" in the next century.

- Set up three biomass gasification systems with gas supply nets, to produce gas fuel, heat and electricity with an annual energy output of 3,000 TOE for 3,000 families in daily life use.

- Set up a biomass pyrolysis system to produce gas, oil and solid fuels, heat and 
electricity with an annual energy output of 7,000 TOE.

- Set up production lines to manufacture the two special systems with an annual capacity of 100 sets of gasification system and 5 plants of pyrolysis system.

The total input for this program is 22.25 million US\$, in which about 11.05 million US\$ from domestic sources and another 11.20 million US\$ from International sources.

\subsubsection{The Key R\&D Program of Biomass Energy in $10^{\text {th }}$ "Five-year Plan"}

In order to prompt the development of new and renewable energy resources, in 1995, three commissions, SSTC, SPC and SETC, drawn "A Essential for Developing New and Renewable Energy Resources in China" to give outline for making plans " Planning for 2010". In these two documents, it is the object for 2010 that:

- firewood forest area will have been up to 1,340 hectares or produced 1270 million tones of firewood by 2010;

- the total energy production will have been 4.9 million TOE by developing biomass energy technologies, such as efficient burning, brequitting, gasification and liquefaction, by 2010;

- the total amount of biogas users will have been 12.35 million households and biogas production will have been 4.0 billion $\mathrm{m}^{3}$ or 2.2 million TOE by 2010 .

To arrive at this object, now, a developing plan is being drawn by CBDC under MOST for the $10^{\text {th }}$ Five Year Plan (2000-2005). The table 20 shows the plan in details.

Table 20 Priority projects in "the $10^{\text {th }}$ Five-year Plan"

\begin{tabular}{|c|c|c|c|}
\hline Projects & Scales & Institutes & Location \\
\hline $\begin{array}{l}\text { 1. Gasification } \\
\text { 4-5 MW electricity generation } \\
\text { system by biomass } \\
\text { gasification } \\
\text { - Study on standardilization } \\
\text { and commercialization of } \\
\text { electricity generation system } \\
\text { by biomass gasification }\end{array}$ & $\begin{array}{l}12,000 \text { Mwh electricity } \\
\text { yearly } \\
6 \text { series } \\
60-160 \mathrm{kw}\end{array}$ & $\begin{array}{l}\text { Guangzhou Energy Institute of } \\
\text { CAS } \\
\text { Liaoning Institute of Energy } \\
\text { Resources } \\
\text { Shandong Institute of Energy } \\
\text { Resources } \\
\text { Nanjing Institute of Forest } \\
\text { Chemical Products } \\
\text { Secretary Office of China } \\
\text { Biomass Development Center }\end{array}$ & $\begin{array}{l}\text { Guangdong } \\
\text { Yingkou } \\
\text { Shandong } \\
\text { Nanjing } \\
\text { Beijing }\end{array}$ \\
\hline $\begin{array}{l}\text { 2. Biogas } \\
\text { - } 2 \mathrm{MW} \text { electricity generation } \\
\text { system by biogas }\end{array}$ & $6,000 \mathrm{Mwh}$ electricity yearly & $\begin{array}{l}\text { Hangzhou Institute of Energy } \\
\text { and Environment }\end{array}$ & Hangzhoui \\
\hline
\end{tabular}

\subsubsection{High technology development in“863” Research Program (2001-2005)}

A high technology development program will be conducted in China from 2001 to 2005, named as " 863 "Research Program. In this program, some new technologies will be concerned as developing key biomass projects in next ten years. These research projects are shown in Table 21. 
Table 21 Biomass research projects in 863 programs

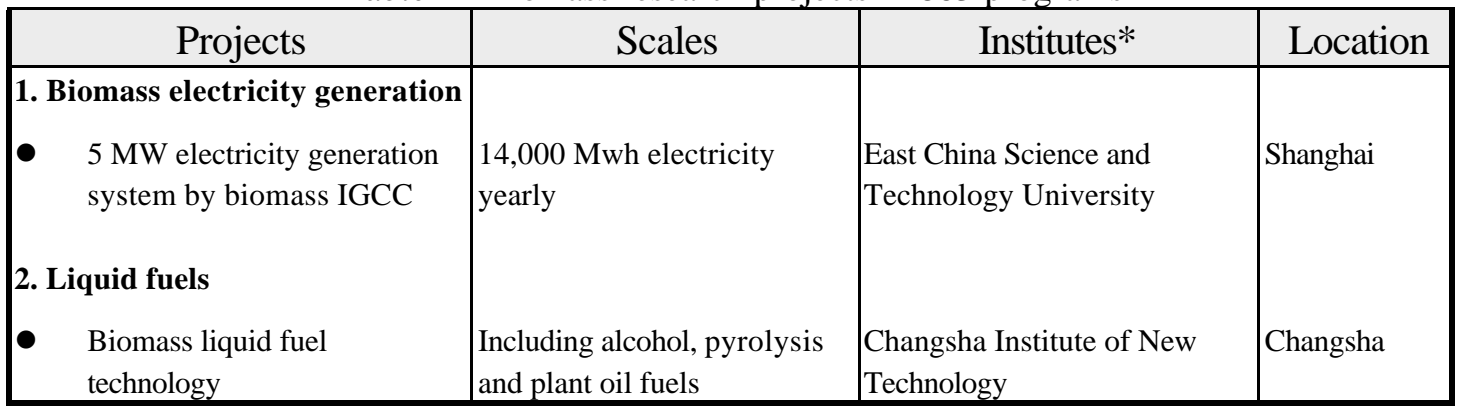

*Note: Institutes in table are bodies that give out related proposals.

\subsection{Major Constraints}

Even though, China has made a great achievement on utilization of biomass as energy, it is still facing some constraints in fields of technology, economy, finance, policy and others. These problems should be resolved in the near future so that its long term object could be achieved successfully.

- Firstly, some new technologies, such as biomass liquefaction, alcohol production from cellulose materials, gasification and pyrolysis, at low levels are a big constraint for their development. Main problems may be involved to low energy conversion efficiency, high energy consumption for system itself, low degree of automation and small capacity. These technical problems will cause a series of economical problems, such as a high operation and management cost on these biomass systems.

- Secondly, there is no an available policy to prompt the development of biomass energy conversion technologies in China, like in west countries.

- Finally, money is a big problem. Some biomass energy technologies could not be demonstrated and used in large scales and at high speeds due to a serious lack of financial input.

- All of problems mentioned above will hinder biomass energy going into energy markets and losing opportunities for its development. In order to promote the exploitation and utilization of biomass energy, it is important to get international technical and economical assistance and to establish demonstration plant and production base of manufacture special equipment.

\section{Suggestions for Priority activities for inter-country/regional Cooperation}

For developing biomass energy in a large scale, it is necessary and possible that some international and/or regional cooperation activities be conducted by countries in the region of Asia and Pacific in a wide field. Most of these countries, including China, are developing countries and they have a common situation on prompting economy growth, developing new energy resources, improving environmental quality. In these countries, biomass resources are used as a major energy source, especially in their rural areas. I am certainly believing that the more such activities we do, the more benefits will we share on energy and environment.

By considering Chinese experiences in developing biomass energy, its constraints in fields of technology and economy and its requirements for international aids, priority activities on inter-country and regional cooperation could be suggested as following: 
- to set up a regional foundation by a cooperation between governments of countries in the region;

- to set a development center by experts from countries in the region;

- to exchange information between these countries through international meetings, magazines and visiting activities;

- to confirm priority projects and technologies being suitable for these countries;

- to helping those countries being lack of experts by making plans on utilization of biomass energy;

- to conduct cooperation research works between experts from these countries, if necessary, to provide financial aids for supporting research cooperation between these countries and developed countries;

- to build some demonstration projects for selected technologies in selected countries and transfer technologies to them;

- to provide technology aids for biomass energy projects and apply financial aids from international organizations or institutes for biomass energy projects.

Some priority technologies are as following:

- biomass gasification and power generation;

- biomass briquetting technology;

- biogas technology for treating animal dung and waste water;

- daily life refuses as energy by biogas, gasification or direct burning;

- biomass liquefaction by a thermal-chemical process.

In addition, an integrated plan should be drawn for developing biomass energy in the region, which will be combined with a national planning by a special country.

China is a developing country. It will do its best to prompt the development of biomass energy technology in the whole region. 


\section{References}

1. Statistical Yearbook of China, China Statistical Publishing House, 1994.

2. Rural Statistical Yearbook of China, China Statistical Publishing House, 1994.

3. Statistical Yearbook of China, China Statistical Publishing House, 1998.

4. Rural Energy Statistical Yearbook of China, China Statistical Publishing House, 1998.

5. Statistical Yearbook of China, China Statistical Publishing House, 2000.

6. Rural Energy Statistical Yearbook of China, China Statistical Publishing House, 2000.

7. New and Renewable Energy - Technologies and Products in China, State Science \& Technology Commission of China, 1995.

8. A report on development of energy in China, Yan Changle et al, Economy Management Press, 1994.

9. A Essential Workframe for Developing New and Renewable Energy Resources in China, SSTC, SPC and SETC, 1995.

10. Priority Projects on Developing New and Renewable Energy Resources in China, SSTC, 1995.

11. A Prediction Research Works on Energy Demand for 2050 in China, Zhou Xiaoqian et al, the Integrated Planning Division of Ministry of Energy, 1990.

12. New and Renewable Energy Technology and Products in China, SSTC, 1995.

13. An Index of Institutes for New and Renewable Energy in China, SSTC, 1996.

14. Biomass Gasification in China, Yuan Zhenhong, Workshop on Biomass Production and Utilization, Trieste, Italy, 1996, 5.

15. A Strategy Evaluation Research on Solid Fuel Technology from Biomass in China, Lin Guofen et al, Research Report for the National Planing by SSTC, 1995.

16. Research and Development Works on Biomass Energy Conversion Technology in China, Yuan Zhenhong et al, A Report to SSTC, 1994.

17. A Strategy Research on Liquid Fuels from Biomass, Yuan Zhenhong et al., A Research Work in the "8th National Five-year Plan for the Development of Science \& Technology" 1995, 6.

18. A Feasibility Research on Priority Projects of Biomass Energy Technology, Yuan Zhenhong et al, A Meeting Report for the Priority Project Plan by SSTC in the Period of the "9th Five Years Plan", 1996,3.

19. A Recycle Fluid System for Gasification of Biomass, Xu Bingyan et al., A Research Work put in the "8th National Five-year Plan for the Development of Science \& Technology" 1995, 12.

20. A research Work on Catalysis Gasification and its Kinetics for Wood Materials, Jiang Jianchun et al., A Research Work put in the "8th National Five-year Plan for the Development of Science \& Technology" 1993, 7.

21. ND-600 Gasifier for Crop and Forest Residues and its Utiliztion, Yang An et al., A workshop on Technologies for Development of New Fuels, the Ministry of Agriculture, 1992.

22. Exploitation and Utilization of Biomass and the Establishment of Demonstration Project, Yuan Zhenhong et al., Proposal Submitted to priority Projects of "21st Century Agenda of China" 1995.

23. Research Works on Gasification of Biomass and its Key Technology in China, Xu Binyan et al., New Energy, 1995,17(12).

24. The Status of Biomass Energy Technology and its Utilization in China, He Yuanbin et al., a Workshop on Biomass Utilization, AIT, Bangkok, 1995, 9.

25. Present Situation and Research on Fuelwood Forest in China, Guo Huairang, Research and Development of Biomass Energy Technology in China, China Science \& Technology Press, 1992

26. Present Situation of Biomass Resources and Their Utilization in China, Xiong Chengyong et al., Research and Development of Biomass Energy Technology in China, China Science \& Technology Press, 1992, 7.

27. Evaluation and Utilization of Biomass Energy Resources in China, Wang Mengjie, Research and Development of Biomass Energy Technology in China, China Science \& Technology Press, 1992, 7.

28. Biomass Pyrolysis Gasification Technology and Gas Supplying Network in a village, Sun Li et al., Research and Development of Biomass Energy Technology in China, China Science \& Technology Press, $1992,7$. 